\title{
THE STRUCTURE OF CHYMOSTATIN, A CHYMOTRYPSIN INHIBITOR
}

\author{
Kuniaki Tatsuta, Nobuyoshi Mikami, Koichi Fujimoto and Sumio Umezawa \\ Department of Applied Chemistry, Faculty of Engineering, Keio University \\ Hiyoshi, Yokohama, Japan
}

\author{
Hamao Umezawa and TakaAki Aoyagi \\ Institute of Microbial Chemistry \\ Kamiosaki, Shinagawa-ku, Tokyo, Japan
}

(Received for publication July 5, 1973)

\begin{abstract}
Chymostatin, a chymotrypsin inhibitor, was shown to be a mixture of components $\mathrm{A}, \mathrm{B}$ and $\mathrm{C}$. The structure of component $\mathrm{A}$ as determined to be $N-[((\mathrm{S})-1$-carboxy-2-phenylethyl)carbamoyl]- $\alpha$-[2-iminohexahydro-4(S)-pyrimidy1]-L-glycyl-L-leucyl-phenylalaninal. Components $B$ and $C$ differed only in that the L-leucyl residue was replaced by L-valine and Lisoleucine, respectively.
\end{abstract}

A microbial product, chymostatin, which inhibits chymotrypsin and papain, was discovered by H. UmezAwA et al. ${ }^{11}$ in 1970 by testing the anti-chymotrypsin activity of culture filtrates. We wish to report the structural elucidation of chymostatin.

Since the amino acid analysis of different samples gave variable ratios of phenylalanine, leucine, valine and isoleucine, chymostatin was considered to be a mixture of similar peptides with minor differences. Attempts to separate the components were unsuccessful.

Chymostatin was sparingly soluble in all solvents except acetic acid and dimethylformamide. It gave a positive test with triphenyltetrazolium chloride but was negative to ninhydrin, suggesting the presence of a reducing function and the absence of a free amino group.

Partial hydrolysis of chymostatin with $1 \mathrm{~N}$ hydrochloric acid in acetic acid (sealed tube, $120^{\circ} \mathrm{C}$, 40 minutes) gave leucine, valine and a trace of isoleucine, together with three ninhydrin-negative compounds: 1 [monohydrochloride-monohydrate: mp $216 \sim 220^{\circ} \mathrm{C}$ (dec.)], 2 (a mixture of 2a, 2b and $2 \mathrm{c})$ and $3\left(\mathrm{mp} 47^{\circ} \mathrm{C}\right)$ (Chart 1$)$.

Hydrolysis of 1 with $1 \mathrm{~N}$ hydrochloric acid at $145^{\circ} \mathrm{C}$ for 72 hours gave DL-phenylalanine, a new basic amino acid (4) and ninhydrin-negative compounds (7a and $7 \mathbf{b}$ ) which will be described later in detail.

The compound 4 ( $4 a$ and $4 b$ ) showed three $\mathrm{pKa}$ values $(<2,7.5$ and $>12)$ in water, suggesting the presence of a carboxyl, an amino and a strong basic group. On treatment with anhydrous methanol and acetic anhydride, 4 was converted into its di- $N$-acetyl-monomethyl ester (5). The nature of the derivative was confirmed by the NMR spectrum. The high resolution mass spectrum of $\mathbf{5}$ showed $m / e$ 228.1215, which corresponds to $\mathrm{M}^{+}-\mathrm{CH}_{2}=\mathrm{C}=\mathrm{O}$. From these results, and their elemental analyses the most probable empirical formulae of 5 and 4 were concluded to be $\mathrm{C}_{11} \mathrm{H}_{18} \mathrm{~N}_{4} \mathrm{O}_{4}$ and $\mathrm{C}_{6} \mathrm{H}_{12} \mathrm{~N}_{4} \mathrm{O}_{2}$, respectively.

However, the NMR spectrum (in $\mathrm{D}_{2} \mathrm{O}$ and 1 equivalent $\mathrm{DCl}$ ) of 4 showed that it was a mixture of diastereomers containing a common sequence of $-\mathrm{CH}_{2}-\mathrm{CH}_{2}-\mathrm{CH}-\mathrm{CH}_{1}-$. This was supported by the presence of $\alpha$-methine doublets at $\delta 4.65$ and 4.67 in the NMR spectrum of 5 which was also mixture 
of the diastereomers.

Fractional crystallization of di-flavianate of 4 from water gave two kinds of di-flavianates, from which two optical isomers $\mathbf{4 a}$ and $\mathbf{4 b}$ were obtained. Their molecular formulae and $\mathrm{pKa}$ values were then found to be identical with those of capreomycidine ${ }^{21}$ which is a constituent of capreomycin. The fragmentation pattern of 5 also agreed with that of the corresponding derivative of capreomycidine. Moreover, the physicochemical properties (the NMR spectrum is shown in Fig. 1) of $\mathbf{4 b}$ proved to be identical with those of capreomycidine except for the sign of their optical rotations (Fig. 2), indicating that $\mathbf{4 b}$ is the D-enantiomer of capreomycidine. The $\alpha$-D-configuration of $4 \mathrm{~b}$ was also deduced by applying the Clough-Lutz-JIRGensons rule ${ }^{3 a}$ to the optical rotations of $\mathbf{4 b}$.

On the other hand, the physicochemical properties (NMR spectrum: Fig. 1; ORD curve: Fig. 3 ) of $4 a$ differed from those of $\mathbf{4 b}$ and capreomycidine. The optical rotation of $\mathbf{4 a}$ showed incomprehensible behavior under different conditions (in water, 1 eq. of $\mathrm{HCl}$ and water, 2 eq. of $\mathrm{HCl}$ and water, and $6 \mathrm{~N} \mathrm{HCl}$ ), and the configuration of the $\alpha$-carbon atom could not be deduced by application of the CLUGH-LUTZ-JIRGENSONS rule.

Treatment of $4 \mathbf{a}$ with $1 \mathrm{~N}$ deuterochloric acid at $140^{\circ} \mathrm{C}$ for 48 hours gave a mixture containing equal amounts of deuterated diastereomers $\mathbf{4 a}$ and $\mathbf{4 b}$. In the NMR spectrum, no signals for the $\alpha$-methines of both deuterated $4 a$ and $4 b$ were discerned because of deuterium exchange of their protons. Similar treatment of $4 \mathrm{~b}$ with deuterochloric acid gave the same phenomenon. These
Chart 1.

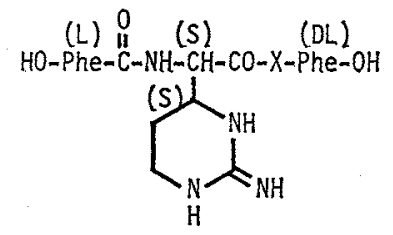

$9(X=$ L-Leu, L-VaI \& L-I1e)

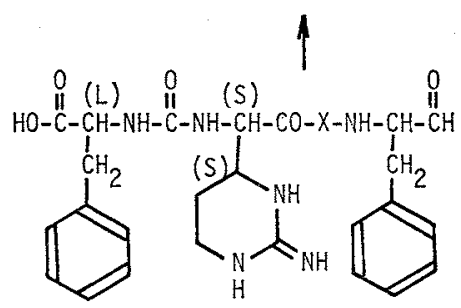

Chymostatin $A: X=L-L e u$

Chymostatin $B: X=L-V a T$

Chymostatin $C: X=L-I$ Ie

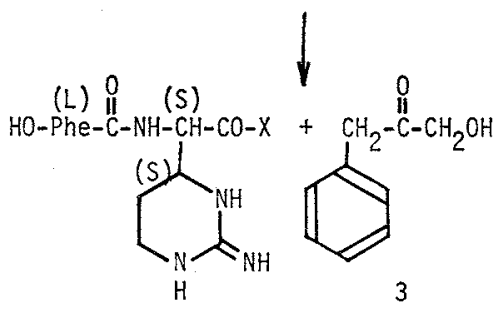

$$
\begin{aligned}
1: X & =O H \\
2 a: X & =\text { L-Leu-OH } \\
2 b: X & =\text { L-VaT-OH } \\
2 c: X & =\text { L-Ile-OH }
\end{aligned}
$$

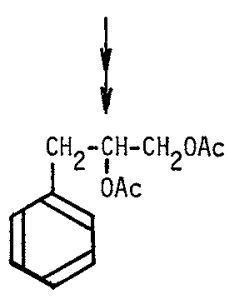

8 results indicated that racemization occurred at the $\alpha$-methine of 4 , but not at the $\beta$-methine during the acid-hydrolysis of 1 . Consequently, $4 a$ differs from $4 \mathbf{b}$ only in the configuration of the $\alpha$-carbon atom, indicating that the $\alpha$-carbon atom of $\mathbf{4 a}$ has L- (or S-) configuration and, accordingly, the $\beta$ carbon atom has S-configuration. Thus, the new basic amino acids $\mathbf{4 a}$ and $\mathbf{4 b}$ were determined to be $\alpha$-[2-iminohexahydro-4(S)-pyrimidyl]-L-glycine and $\alpha$-[2-iminohexahydro-4(S)-pyrimidyl]-D-glycine, respectively (Chart 2 ).

The NMR spectrum $\left(\mathrm{D}_{2} \mathrm{O}\right.$, Fig. 4) of $\mathbf{1}$, however, showed that $\mathbf{1}$ had only a single component, which consisted of either of D- or L-phenylalanine and either of $4 a$ or $4 \mathbf{b}$. The molecular weight of the hydrochloride of 1 was estimated to be approximately four hundred by the vapor pressure osmometer and three pKa values $(<3,3.9$ and $>12)$ of 1 in water indicated the presence of two carboxyl groups and a strong basic group. A drastic hydrazinolysis (in a sealed tube, at $120^{\circ} \mathrm{C}$, overnight) of 1 gave 
Chart $1^{\prime}$.
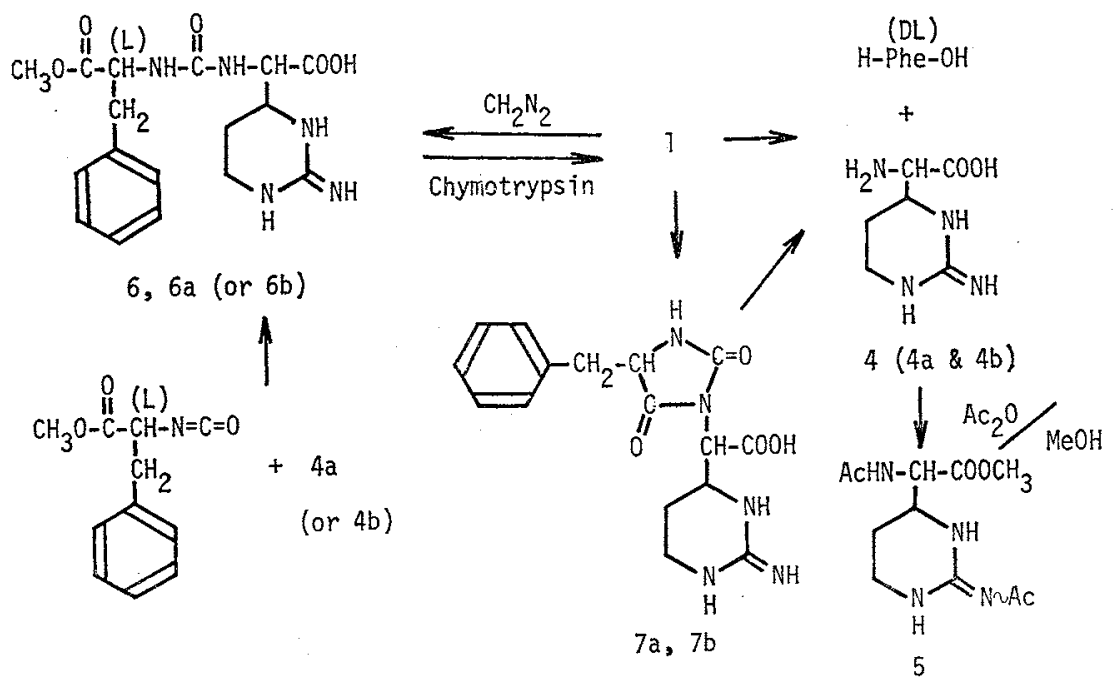

Fig. 1. NMR spectra of $4 \mathrm{a}, 4 \mathrm{~b}$ and capreomycidine (Cap.) in $\mathrm{D}_{2} \mathrm{O}+1$ eq. $\mathrm{DCl}$ at $100 \mathrm{MHz}$

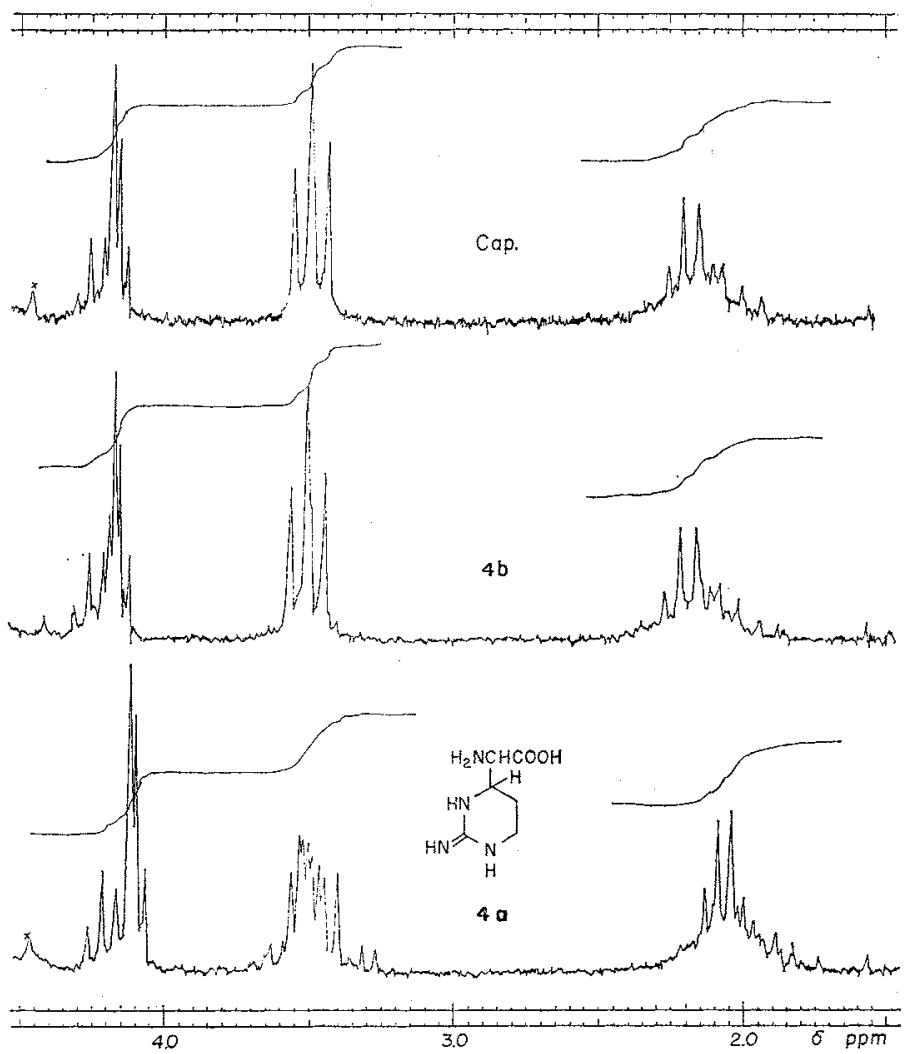

phenylalanine as a single C-terminal amino acid. Consequently, the other C-terminal amino acid is the amino acid 4, although this was decomposed by hydrazinolysis and could not be detected. The natural-abundance carbon-13 FourIER transform NMR spectrum (in $\mathrm{D}_{2} \mathrm{O}$; Fig. 5 ) of 1 showed the presence of sixteen carbon atoms, fifteen of which were due to the moieties of phenylalanine (nine carbon 
Fig. 2. ORD curves of $4 \mathrm{~b}$ (in $\mathrm{H}_{2} \mathrm{O}$; in $\mathrm{H}_{2} \mathrm{O}+$ 2 eq. $\mathrm{HCl}$ ) and capreomycidine (in $\mathrm{H}_{2} \mathrm{O}$; in $\mathrm{H}_{2} \mathrm{O}+2$ eq. $\mathrm{HCl}$ )

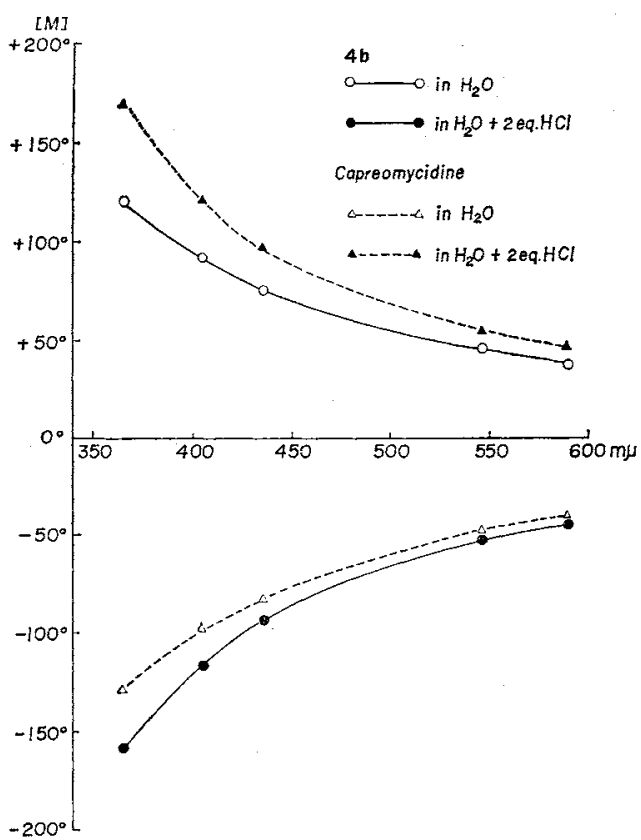

Fig. 3. ORD curves of $4 \mathrm{a}$ in water, water and 1 eq. $\mathrm{HCl}$, water and 2 eq. $\mathrm{HCl}$, and $6 \mathrm{~N} \mathrm{HCl}$

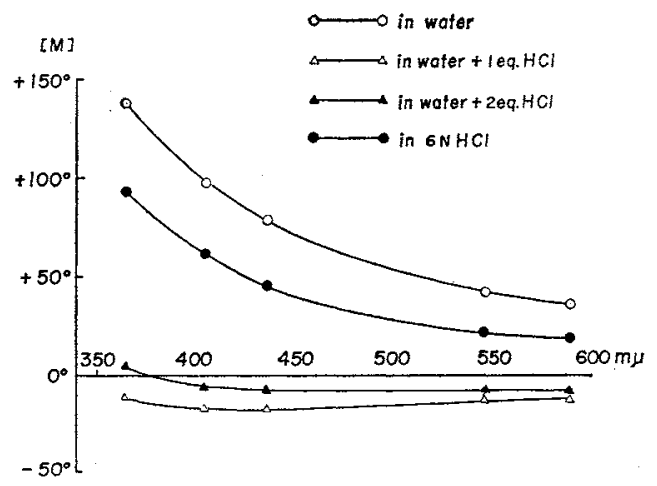

Chart 2.



$4 a$

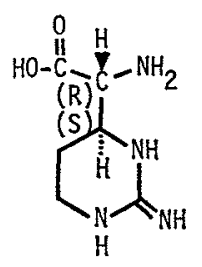

$4 b$

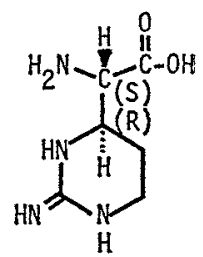

Capreomycidine

Fig. 4. NMR spectrum of monohydrochloride of 1 in $\mathrm{D}_{2} \mathrm{O}$ at $100 \mathrm{MHz}$

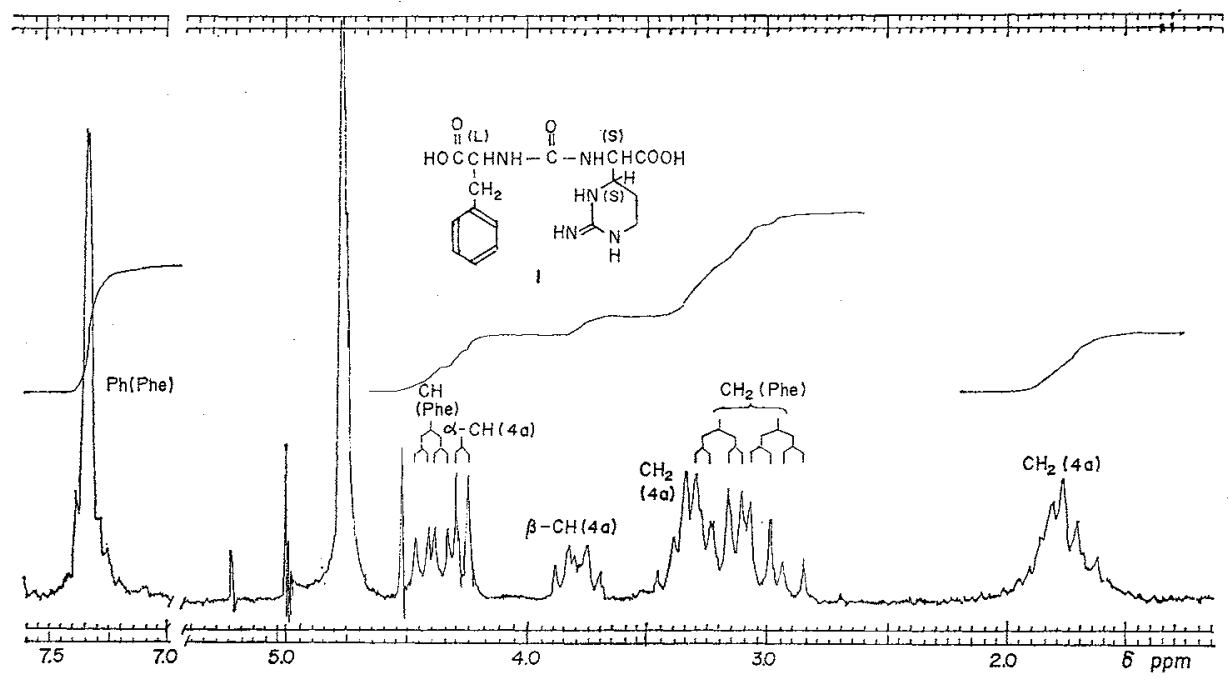

atoms) and 4 (six carbon atoms). The residual one carbon atom was assigned to a carbonyl carbon because of its lower field resonance. From the above results, 1 was assumed to be an ureido-type derivative composed of phenylalanine and 4.

Next, the absolute stereochemistry of the phenylalanine and 4 in 1 was established by preparing the monomethyl ester (6) of $\mathbf{1}$ by different routes as follows. Treatment of $\mathbf{1}$ with diazomethane gave, 
Fig. 5. ${ }^{13} \mathrm{C}-\mathrm{NMR}$ spectrum of monohydrochloride of $1 \mathrm{NV}-14{ }^{13} \mathrm{C}-\mathrm{FT}$ spectrum. Sample: about $200 \mathrm{mg} /$ $2 \mathrm{ml}$ in $\mathrm{D}_{2} \mathrm{O}$. Transients: 10,000. Acquisition time: $0.8 \mathrm{sec}$. Spectrum width: $2,500 \mathrm{~Hz}$. Proton noise decoupled. $\delta$-Values relative to dioxane $=67.1$

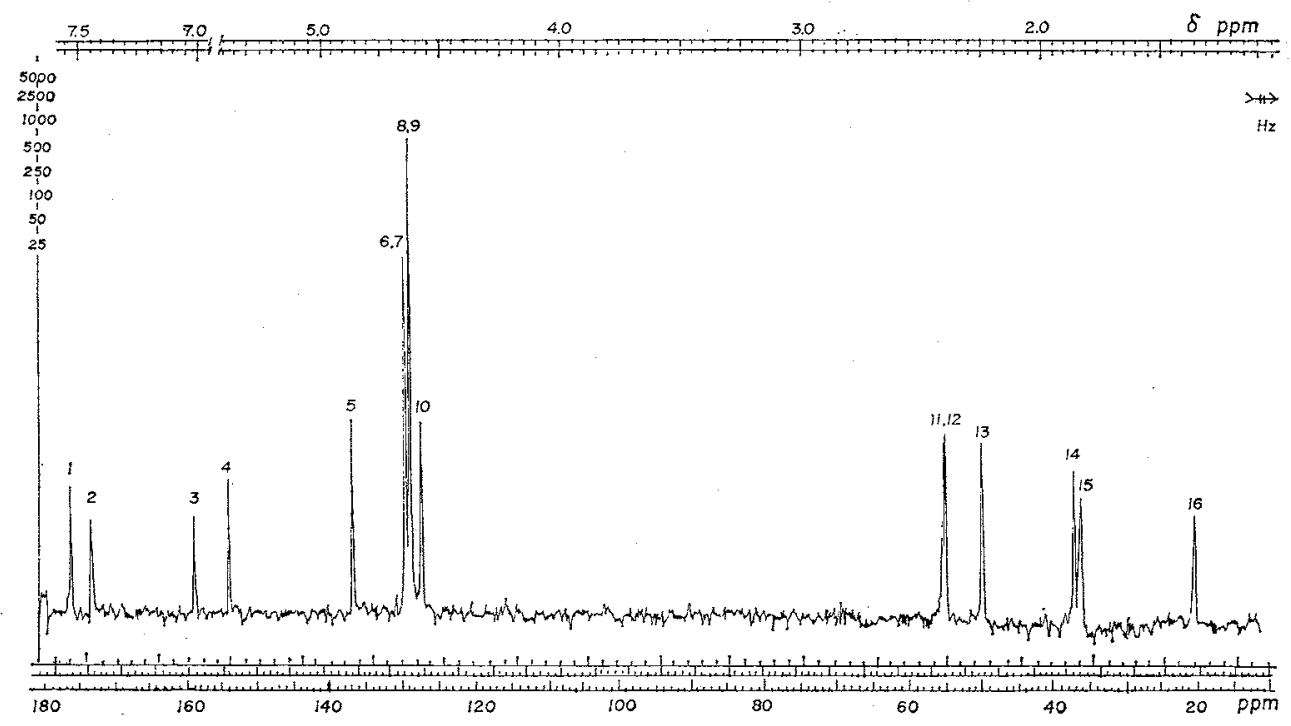

in $70 \%$ yield, the monomethyl ester 6 [monohydrochloride: $[\alpha]_{D}^{17}+28.5^{\circ}$ (methanol)] which was expected since a zwitter ion should form between the carboxyl and guanidino groups of the constituent 4, leaving only the carboxyl group of the phenylalanine moiety susceptible to esterification. Digestion of the 6 at pH 6 and $27^{\circ} \mathrm{C}$ overnight with $\alpha$-chymotrypsin, which specifically splits the peptide or ester bond adjacent to the carbonyl of L-phenylalanine gave quantitatively the original 1 , indicating that only the carboxyl group of phenylalanine had been esterified and, moreover, that the phenylalanine in $\mathbf{1}$ was the L-isomer. Therefore, of the four possible structures for 6 (or 1), the two containing D-phenylalanine moieties could be ruled out. Next, in order to distinguish between the two possible structures containing L-phenylalanine, the isocyanate of L-phenylalanine methyl ester was synthesized and condensed with natural $4 \mathrm{a}$ and $\mathbf{4 b}$ in dimethylsulfoxide, giving $6 \mathrm{a}$ [monohydrochloride: $[\alpha]_{D}^{17}+28.5^{\circ}$ (methanol)] in $70 \%$ yield and $6 \mathrm{~b}$ [monohydrochloride: $[\alpha]_{\mathrm{D}}^{17}+6.5^{\circ}$ (methanol)] in $73 \%$ yield, respectively. Compounds $4 \mathrm{a}$ and $\mathbf{4 b}$ were used directly in the condensation since their carboxyl and guanidino groups were expected to form a zwitter ion and to be unreactive to the isocyanate. This expectation was realized. Hydrolysis of $6 \mathrm{a}$ with $\alpha$-chymotrypsin gave a compound identical with $\mathbf{1}$, whereas $\mathbf{6} \mathrm{b}$ gave an isomer $\left(\mathbf{1}^{\prime}\right)$ of 1 which was assumed to be composed of L-phenylalanine and $\mathbf{4 b}$. Compounds 1 and $\mathbf{1}^{\prime}$ were distinguishable on a silica gel thin-layer chromatogram with the solvent system: $n$-butanol ethanol - water (4:1:2); 1: Rf 0.35 and $1^{\prime}:$ Rf 0.31 . The physicochemical properties (NMR spectra: Fig. 6; ORD curves: Fig. 7) of 6, 6a and $6 \mathrm{~b}$ indicated that natural 6 was identical with $6 \mathrm{a}$, but not with $6 \mathrm{~b}$, and therefore 6 was a ureide of L-phenylalanine methyl ester and $\alpha$-[2-iminohexahydro-4(S)pyrimidyl]-L-glycine. Thus, the structure of 1 could be established as $N$-[((S)-1-carboxy-2-phenylethyl)carbamoyl]- $\alpha$-[2-iminohexahydro-4(S)-pyrimidyl]-L-glycine.

Milder treatment of 1 with $1 \mathrm{~N}$ hydrochloric acid $\left(105^{\circ} \mathrm{C}, 24\right.$ hours) gave only compounds $7 \mathrm{a}$ and $7 \mathbf{b}$ (as noted earlier) in a ratio of approximately $3: 1$. These gave, on further hydrolysis $\left(140^{\circ} \mathrm{C}, 48\right.$ hours), a stereoisomeric mixture of phenylalanine and 4. The NMR spectra (in $\mathrm{CF}_{3} \mathrm{COOD}$ or 
Fig. 6. Parts of NMR spectra of monohydrochlorides of $6,6 \mathrm{a}$ and $6 \mathrm{~b}$ in DMSO-d at $100 \mathrm{MHz}$

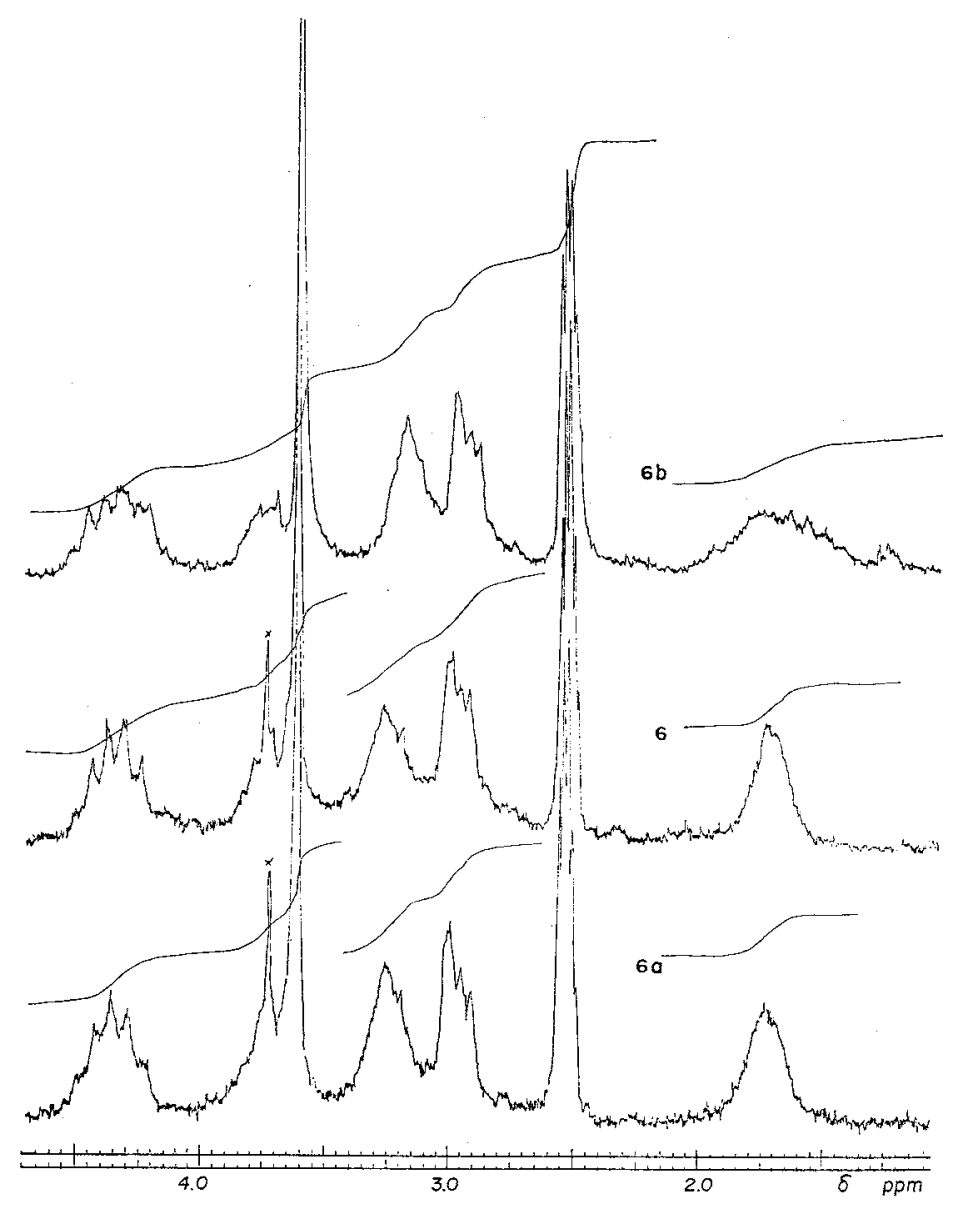

DMSO- $\mathrm{d}_{6}$ ) of $7 \mathrm{a}$ and $7 \mathrm{~b}$ and ${ }^{13} \mathrm{C}-\mathrm{NMR}$ spectrum (in DMSO- $\mathrm{d}_{6}$; Fig. 8) of 7a indicated that $7 \mathbf{a}$ and $7 \mathrm{~b}$ contained the same constituents as 1 , except that both $7 \mathbf{a}$ and $7 \mathbf{b}$ had equal amounts of two components because of their double (1:1) signals. These results showed that $7 \mathbf{a}$ and $7 \mathbf{b}$, as a whole, were composed of all of the four compounds anticipated from the consituents of $\mathrm{D}$ - or $\mathrm{L}$ phenylalanine and $\mathbf{4 a}$ or $\mathbf{4 b}$. On treatment of $7 \mathbf{a}$ or $7 \mathbf{b}$ with $1 \mathrm{~N}$ hydrochloric acid, partial conversion to $7 \mathbf{b}$ or $7 \mathbf{a}$ respectively was observed. Compounds $7 \mathrm{a}$ and $7 \mathrm{~b}$ were basic substances and the pKa values of both (in $50 \%$ aq. methanol) were $\sim 2.9$ and $>12$, indicating the presence of a carboxyl group and a strong basic group and the absence of the second carboxyl group which was observed in 1 . Drastic hydrazinolysis of $7 \mathbf{a}$ and $7 \mathbf{b}$ gave no phenylalanine, indicating that the carboxyl groups of the phenylalanine moieties were not free.

Comparing the NMR spectra (in DMSO- $\mathrm{d}_{6}$ ) of $\mathbf{7 a}$ and $\mathbf{7 b}$ with that of $\mathbf{1}$, revealed that the $\alpha$-imino 
Fig. 8. ${ }^{13} \mathrm{C}-\mathrm{NMR}$ spectrum of $7 \mathbf{a}$

XL-100-15 ${ }^{13}$ C-FT spectrum. Sample: about $200 \mathrm{mg} / 2.5 \mathrm{ml}$ in DMSO-d 6 . Transients: 4,000. Acquisition time: $0.4 \mathrm{sec}$. Spectrum width: $5,000 \mathrm{~Hz}$. Proton noise decoupled. $\delta$-Values relative to $\mathrm{TMS}=0$

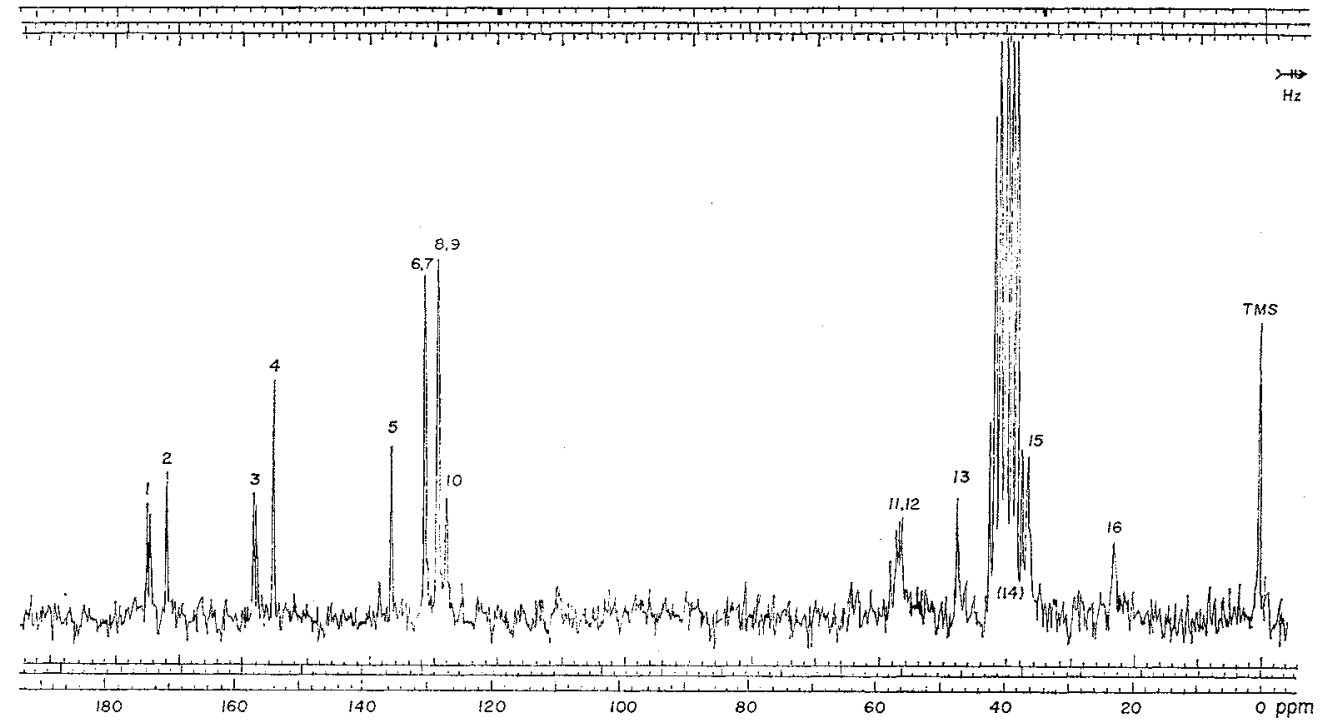

singnals of moiety 4 were absent from $7 \mathrm{a}$ and $7 \mathrm{~b}$ and, moreover, the $\alpha$-imino signals of their phenylalanine moieties were deshielded and were each observed at $\delta \sim 8.7$. These observations suggested that both $7 \mathrm{a}$ and $7 \mathrm{~b}$ were hydantoins involving the carboxyl group of the phenylalanine moiety and the $\alpha$-imino group of moiety 4 in 1 . Moreover, an absorption maximum at $1775 \mathrm{~cm}^{-1}$, which could be assigned to the hydantoin ring, was present in their IR spectra. This finding is in accord with the view that ureido derivatives are converted into hydantoins by treatment with hydrochloric acid." Since optically active hydantoins are known to be racemized in dilute alkaline solution, ${ }^{4)}$ racemization of $7 \mathbf{a}$ and $7 \mathbf{b}$ can be assumed to occur on column chromatography using solvent system containing aqueous ammonia. Treatment of $7 \mathrm{a}$ or $7 \mathrm{~b}$ with $2 \mathrm{~N}$ deuterated ammonia in deuterium oxide and deuteromethanol caused no chromatographic change but did cause the selective disappearance from their NMR spectra of the $\alpha$-methine signals of the phenylalanine moieties. This result indicated that only the $\alpha$-methines of the phenylalanine moieties were racemized in the dilute alkaline solutions used in column chromatography (as distinguished from the experimental section "Preparation of $7 \mathbf{a}$ and $7 \mathrm{~b}$ from 1"). Thus, it is evident that both $\mathbf{7 a}$ and $7 \mathbf{b}$ are mixtures composed of equal amounts of D- and L-phenylalanine - containing constituents, and the $\alpha$-carbon atom and carbonyl groups of their $D, L$-phenylalanine moieties are contained in hydantoin rings.

A milder treatment of 1 with $1 \mathrm{~N}$ deuterochloric acid $\left(105^{\circ} \mathrm{C}, 24\right.$ hours) gave deuterated $7 \mathbf{a}$ and $7 \mathbf{b}$ in a ratio about $3: 1$. In the NMR spectrum of this deuterated $7 \mathrm{~b}$, the $\alpha$-methine signal of moiety 4 was not discerned because of deuterium exchange. The NMR spectrum of deuterated 7a showed that about $10 \%$ of the $\alpha$-methine of moiety 4 was exchanged with deuterium. These findings suggested that the $4 \mathrm{a}$ moiety of 1 would be racemized partially to the $4 \mathrm{~b}$ structure by a keto-enol tautomerism, and that $7 \mathrm{a}$ and $7 \mathrm{~b}$ contained the original $4 \mathrm{a}$ moiety and the transformed $4 \mathrm{~b}$ moiety, respectively. The easy racemization of the $\alpha$-carbon atom of moiety 4 may be due to keto-enol tautomerism accelerated 
by protonation at $\mathrm{N}-3$ (Chart 3 ).

The $\alpha$-methines of the phenylalanine moieties of $7 \mathbf{a}$ and $7 \mathbf{b}$ were not exchangeable with deuterium in the mild treatment of 1 with deuterochloric acid mentioned above. The NMR spectrum of a mixture of $\mathbf{7 a}$ and $7 \mathbf{b}$, prior to separation by column chromatography using aqueous ammonia, showed no change in
Chart 3.

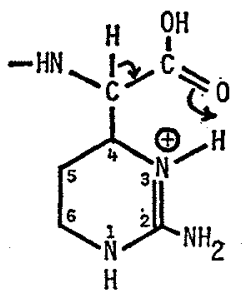

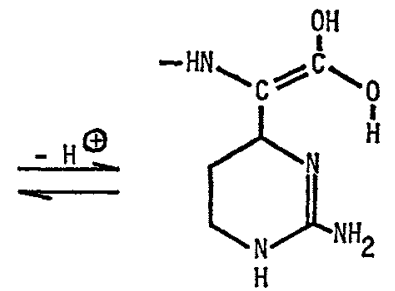
the $\alpha$-methine signals of their phenylalanine moieties.

From these results, $7 \mathrm{a}$ was deduced to have a hydantoin structure composed of D,L-phenylalanine and $4 a$, and $7 b$ to have one composed of D,L-phenylalanine and $4 b$. No hydantoin containing the $\alpha$-carbon atoms and carboxyl groups of $\mathbf{4 a}$ and $\mathbf{4 b}$ within the ring was observed.

Treatment of $7 \mathrm{a}$ (or $7 \mathrm{~b}$ ) with sodium hydroxide gave a mixture of compounds with the same $\mathrm{Rf}$, 0.35 and 0.31 , as $\mathbf{1}$ and isomer $\mathbf{1}^{\prime}$, respectively.

Next, the structural elucidation of $\mathbf{2}(\mathbf{2} \mathbf{a}, \mathbf{2} \mathbf{b}$ and $\mathbf{2 c})$ will be described.

Column chromatography of hydrolysates of chymostatin gave $\mathbf{2 a}$ and $\mathbf{2 b}$ : the ratio was approximately 10: 1 .

Compound $2 \mathrm{a}$ was hydrolyzed with $0.1 \mathrm{~N}$ hydrochloric acid at $120^{\circ} \mathrm{C}$ for 30 minutes to give 1 and L-leucine. Also, digestion of $2 \mathrm{a}$ with carboxypeptidase $\mathrm{A}\left(\mathrm{pH} 8.0,27^{\circ} \mathrm{C}, 3\right.$ hours), which splits specifically at the site of the amino group of the C-terminal L-amino acid, gave 1 and leucine, implying that leucine was the L-isomer and one of the C-terminal amino acids of $2 a$. Compound 1, however, was not further degraded with carboxypeptidase A, probably because of the presence of a ureylene group. Drastic hydrazinolysis of 2a gave two C-terminal amino acids, phenylalanine and leucine, indicating that the amino group of L-leucine forms an amide linkage with the carboxyl group of the moiety 4 a. The pKa values $(\sim 4,5.6$ and $>13)$ of $2 \mathrm{a}$ in $60 \%$ aqueous dimethylformamide showed the presence of two carboxyl groups and one strong base, supporting the proposed structure.

Similarly, acid hydrolysis, digestion with carboxypeptidase $\mathbf{A}$, and hydrazinolysis of $\mathbf{2 b}$ indicated that $\mathbf{2 b}$ is composed of $\mathbf{L}$-valine and $\mathbf{1}$, linked by an amide bond formed between the amino group of valine and the carboxyl group of moiety 4a. The NMR spectra and elemental analyses of $2 \mathbf{a}$ and 2b were consistent with the structures postulated.

A drastic hydrazinolysis of chymostatin gave only phenylalanine as a C-terminal amino acid, suggesting that leucine of $\mathbf{2 a}$, valine of $\mathbf{2 b}$ and probably isoleucine of $\mathbf{2 c}$ respectively were bound to another constituent through their carboxyl groups.

The other constituent (3), which could be extracted with ether from the acid hydrolyzates of chymostatin, was optically inactive and gave a positive with triphenyltetrazolium chloride reagent for a reducing compound. The mass spectrum showed the highest peak at $m / e 151$, which probably corresponded to $\mathrm{M}^{+}+1$ because the elemental analysis of 3 showed only the presence of carbon (71.90\%), hydrogen $(6.69 \%)$ and oxygen $(21.35 \%)$ atoms. Thus the most probable empirical formula of 3 is $\mathrm{C}_{9} \mathrm{H}_{10} \mathrm{O}_{2}$ (molecular weight: 150). The NMR spectrum (in $\mathrm{CDCl}_{3}$ ) of 3 showed one hydroxyl signal at $\delta 3.0$, which disappeared upon deuteration, two methylene singlets at $\delta 3.77$ and $\delta 4.33$, and one phenyl signal at $\delta \sim 7.35$. Hydrogenation of 3 with zinc borohydride ${ }^{5}$ under neutral conditions, followed by acetylation with acetic anhydride and pyridine gave the diacetyl derivative 8 in $86 \%$ yield. Its NMR 
spectrum (in $\mathrm{CDCl}_{3}$ ) showed the presence of the chain $-\mathrm{CH}_{2}-\mathrm{CH}_{1}-\mathrm{CH}_{2^{-}}$, two O-acetyl groups and one phenyl group. Taking into account its mass spectrum $\left(\mathrm{M}^{+} 236\right)$ and elemental analysis 8 is considered to be 1,2-di-O-acetyl-3-phenylpropane. Therefore, the parent 3 should be 1-hydroxy-3-phenyl2-propanone, and this was confirmed by comparison with an authentic sample.

However, chymostatin showed, in its ultraviolet spectrum, molar absorptivities at the wavelengths of maximum absorption essentially equal to the sum of those of the constituents $2 \mathbf{a}$ (or $\mathbf{2 b}$ ) and $\mathbf{3}$, and, when treated with acidic methanol and acidic $n$-butanol, chymostatin gave a dimethyl acetal and a di-n-butyl acetal respectively. Their structures were supported by the $O$-methyl signals $(\delta \sim 3.4 ; 6 \mathrm{H})$ and $O-n$-butyl signals $\left(\delta 0.5 \sim 1.7\right.$ and $\delta 3.3 \sim 3.7 ; 18 \mathrm{H}$ in total) in their NMR spectra (DMF- $\mathrm{d}_{7}$ ), and suggested the presence of an aldehyde group in chymostatin. This result was also consistent with the presence of an aldehyde singlet at $\delta 9.5$ in the NMR spectrum (in DMF- $\mathrm{d}_{7}$ ) of chymostatin. The above findings implied that, an aldehyde-containing precursor, which could be converted to 3 by acid hydrolysis, is present in chymostatin.

Chymostatin was oxidized with potassium permanganate to give the product (9) in about $60 \%$ yield. Though attempted isolations of the pure components were unsuccessful, the results of elemental analyses were essentially in agreement was a structure containing leucine. Hydrolysis of 9 with $1 \mathrm{~N}$ hydrochloric acid $\left(120^{\circ} \mathrm{C}, 40\right.$ minutes) gave new constituents $10 \mathrm{a}$ and $10 \mathrm{~b}$, and DL-phenylanine, in addition to the above-mentioned constituents 1. 2a, $\mathbf{2 b}$, leucine, valine and isoleucine. Compound $\mathbf{3}$, however, was not detected in this hydrolysate, indicating that this moiety was changed by oxidation. Further acid-hydrolysis of $10 \mathrm{a}$ and $10 \mathrm{~b}$ gave L-leucine and DL-phenylalanine, and L-valine and DL-phenylalanine, respectively. The EDMAN degradation ${ }^{6)}$ of $10 \mathrm{a}$ and $10 \mathrm{~b}$ gave the phenylthiohydantoins of leucine and valine respectively as $\mathrm{N}$-terminal amino acids in addition to intact phenylalanine as $\mathrm{C}$-terminal amino acids in common. These results suggested that 10a and $10 \mathrm{~b}$ are L-leucyl-DL-phenylalanine and L-valyl-DL-phenylalanine respectively, and the identifications were confirmed by synthesis. These findings indicated that 9 was a mixture of components containing 1 and $10 \mathrm{a}$ (or $2 \mathrm{a}$ and DL-phenylalanine), and 1 and $10 \mathrm{~b}$ (or $\mathbf{2 b}$ and $\mathrm{DL}$-phenylalanine) at least. Hydrazinolysis of 9 still liberated phenylalanine as the C-terminal amino acid, supporting this suggestion. Thus, it was proved that, on oxidation of chymostatin, a DL-phenylalanine moiety was generated, indicating that chymostatin originally contained the aldehyde phenylalaninal, which could reasonably be converted to 3 on an acid hydrolysis. Digestion of 9 with carboxypeptidase $\mathrm{A}$ at $27^{\circ} \mathrm{C}$ for 30 minutes also gave 2 and L-phenylalanine. This L-phenylalanine must be a $\mathrm{C}$-terminal amino acid which has originated from the phenylalaninal in chymostatin, because the constituent $\mathbf{1}$, which also has L-phenylalanine as a C-terminal residue, is not attacked by this enzyme. Throughout this enzymatic hydrolysis, some starting material (tentatively named as $9 \mathrm{D}$ ) containing D-phenylalanine as one of the C-terminal amino acids remained unchanged. Partial hydrolysis of $9_{D}$ with hydrochloric acid gave the expected D-phenylalanine as long as 1 remained intact. Further enzymatic digestion (for 3 hours) of the above mixture gave 1, L-phenylalanine, Lleucine, L-valine and L-isoleucine, and the molar ratios of the four amino acids by quantitative amino acid analysis were: 16:10:2:1. Therefore, the original chymostatin was determined to be a mixture composed of a leucine-containing component (chymostatin A), a valine-containing component (chymostatin B), and an isoleucin-containing component (chymostatin C) in molar ratios of approximately $10: 2: 1$.

Based on the aforementioned results, we concluded that structures of chymostatins A, B and C are 
$N$-[((S)-1-carboxy-2-phenylethyl)carbamoyl]- $\alpha$-[2-iminohexahydro-4(S)-pyrimidyl]-L-glycyl-L-leucyl-, Lvalyl- and L-isoleucyl-phenylalaninal, respectively.

From the structural viewpoint, it is noteworthy that chymostatin contains a ureylene and phenylalaninal groups. The ureylene group has been found in antipain ${ }^{7 /}$ inhibiting trypsin and papain. The presence of the phenylalaninal group is interesting, because the peptide bond on the carboxyl side of phenylalanine in peptides undergoes chymotrypsin hydrolysis.

\section{Experimental}

Infrared spectra (IR) were recorded from potassium bromide discs, unless otherwise stated, with a Perkin-Elmer Infared Spectrometer and a Hitachi 285 Infrared Spectrometer. Optical rotation measurements were obtained with a Carl Zeiss Photoelectric Precision Polarimeter $(2 \mathrm{~cm}$ cells). Nuclear magnetic resonance (NMR) spectra were measured on Varian Associates A-60D and HA-100 instruments, and are given in parts per million $(\delta)$ down field from the internal standards: tetramethylsilane for the solution of organic solvents, and sodium 4,4'-dimethyl-4-silapentane-1-sulfonate for the solution of deuterium oxide. Mass spectra were determined on a Hitachi RMU 6D instrument. Molecular weight was determined on a Mechrolab Vapor Pressure Osmometer 300. Amino acid analyses were carried out on a Beckman 120C Automatic Recording Analyser. Thin-layer chromatography (TLC) was performed with silica gel ("Silica-Rider" purchased from Daiichi Pure Chemicals Co.), pre-coated plates ("Replate" purchased from Yamato Kagaku Co.) or microcrystalline cellulose powder ("Avicel" purchased from Funakoshi Yakuhin Co.) and substances were detected by spraying with: (a) ninhydrin reagent: a $0.25 \%$ solution of ninhydrin in pyridine (then heated at $100^{\circ} \mathrm{C}$ for a few minutes); (b) RYDON-SMITH reagent ${ }^{9}$ : An alkaline solution of sodium hypochlorite (antiformin), ethanol (then dried with hot air) and then a mixture of $1 \%$ aqueous starch and $1 \%$ aqueous potassium iodide solution; (c) TTC reagent: a mixture of $4 \%$ methanolic triphenyltetrazolium chloride solution and $1 \mathrm{~N}$ methanolic sodium hydroxide solution (then heated at $100^{\circ} \mathrm{C}$ for a minute) and (d): conc. sulfuric acid (then heated for a few minutes). Column chromatography was performed by the use of silica gel (Mallinckrodt AR-100, unless otherwise stated) or cellulose powder ("Avicel"). Cellulose powder was at first packed with acetone, and then the acetone was replaced with water and finally replaced with the appropriate solvent system for a separation pattern to parallel to that of TLC. Chromatograms were developed in the following solvent systems: A, chloroform - ethyl acetate $(4: 1)$; $\mathrm{B}, n$ butanol-ethanol-chloroform-17\% aqueous ammonia (4:4:2:3); C, $n$-butanol-ethanol-chloroform-17\% aqueous ammonia (4:5:2:4); D, $n$-butanol-acetic acid-water $(3: 1: 2) ; \mathrm{E}, n$-butanol-ethanol-water (4:1:2); F, ethyl acetate-methanol-10\% aqueous acetic acid $(5: 2: 1)$ and $\mathrm{G}$, benzene-ethyl acetate (8:1). The C-terminal amino acid analysis was carried out by the usual hydrazinolysis except for the reaction temperature $\left(120^{\circ} \mathrm{C}\right)$. The resulting solid containing C-terminal amino acids was submitted to quantitative amino acid analysis to distinguish leucine and isoleucine. The $\mathrm{N}$-terminal amino acid analysis was carried out by the usual EDMAN degradation using phenylisothiocyanate. Chymotrypsin and carboxypeptidase used for enzymatic hydrolyses were obtained commercially from Worthington Biochemical Corporation: $\alpha$-chymotrypsin (49 U/mg; CDI) and carboxypeptidase A-DFP (50 U/mg; $92.2 \mathrm{mg} / \mathrm{ml}$; COADFP), respectively.

Chymostatin. Chymostatin used for the present investigation had mp $204 \sim 208^{\circ} \mathrm{C}\left(\mathrm{dec}\right.$.), $[\alpha]_{D}^{21}$ $+10.9^{\circ}$ (c 0.92 , acetic acid).

UV spectrum [in a mixture of acetic acid $(1 \mathrm{ml})$ and methanol $(3 \mathrm{ml})$ ]: $\lambda_{\mathrm{max}}(\varepsilon) \sim 278(380), 268$ (450), 264 (500), 258 (540), 253 (510), $247 \mathrm{~m} \mu$ (500).

NMR spectrum (dimethylformamide-d $\left.{ }_{7}\right): \delta 0.88\left[6 \mathrm{H} \mathrm{m},\left(\mathrm{CH}_{3}\right)_{2} \mathrm{CH}\right], 1.2 \sim 2.3(5 \mathrm{H} \mathrm{m}$, two methylenes and one methine), $3 \sim 3.5\left(4 \mathrm{H} \mathrm{m}\right.$, two methylenes), $3.5 \sim 4.1\left(3 \mathrm{H} \mathrm{m}, \mathrm{CH}_{2}\right.$ and $\mathrm{CH}$ ), $4.2 \sim 4.9$ ( $4 \mathrm{H} \mathrm{m}$, four $\alpha$-methines), $5 \sim 5.9$ ( $2 \mathrm{H}$ broad $\mathrm{m}, \mathrm{H}_{2} \mathrm{O}$ ?), $6.5 \sim 7.9(4 \mathrm{H} \mathrm{m}$, four imines), $\sim 7.28(10 \mathrm{H} \mathrm{m}$, two phenyl groups), $8.1 \sim 9.3$ ( $3 \mathrm{H} \mathrm{m}$, three imines), 9.6 (1H s, aldehyde).

Chymostatin is positive to RYDon-SMITH and TTC, but negative to ninhydrin, SAKaguchI 
and diacetyl reagents.

The C-terminal amino acid analysis of chymostatin gave only phenylalanine.

Partial Hydrolysis of Chymostatin (Isolation of 1, 2a, 2b, 3, L-leucine and L-valine). A solution of chymostatin $(1.0 \mathrm{~g})$ in acetic acid $(10 \mathrm{ml})$ and $1 \mathrm{~N}$ hydrochloric acid $(10 \mathrm{ml})$ was heated at $120^{\circ} \mathrm{C}$ for 40 minutes in a sealed tube. The resulting purple solution was shaken with ethyl ehter $(10 \mathrm{ml} \times 3)$. The ethereal layer showed virtually a single spot of Rf 0.50 on a silica gel TLC (Solvent system A), and the aqueous layer showed two ninhydrin-positive spots of Rf 0.58 and 0.52 and four RYDONSMITH - positive spots of $\operatorname{Rf~} \sim 0.7,0.53,0.51$ and 0.25 on a cellulose TLC (Solvent system B).

(a) Isolation of 3: The ethereal layer was washed with water $(3 \mathrm{ml} \times 2)$, dried over sodium sulfate and evaporated to give a solid. The solid $(130 \mathrm{mg})$ was chromatographed on a column of silica gel $(20 \mathrm{~g})$ with Solvent system A and the fraction containing the substance at Rf $0.50(35 \sim 80 \mathrm{ml})$ was evaporated to give crystals. Recrystallization from water gave colorless plates; yield $72.5 \mathrm{mg} ; \mathrm{mp}$ $47^{\circ} \mathrm{C},[\alpha]_{D}^{17} 0^{\circ}$ (c 2.0, $\left.\mathrm{CHCl}_{3}\right)$.

Found: C 71.90, $\mathrm{H} 6.69, \mathrm{O} 21.35 \%$. Calcd. for $\mathrm{C}_{9} \mathrm{H}_{10} \mathrm{O}_{2}$ (mol. wt. 150.17): C 71.98, H 6.71, O $21.31 \%$.

Mass spectrum $(m / e): 151\left(\mathrm{M}^{+}+1\right), 150\left(\mathrm{M}^{+}\right), 120,93,92,90,66,64,52,40$.

IR spectrum: $\sim 3400(\mathrm{OH}), \sim 3050,2900(\mathrm{CH}), \sim 1725(\mathrm{C}-\mathrm{O}), 1605,755,700$ (phenyl), 1075, $1050 \mathrm{~cm}^{-1}(\mathrm{C}-\mathrm{O})$.

UV spectrum: $\lambda_{\max }^{\mathrm{E}+\mathrm{OH}}(\varepsilon) \sim 280(150), 265$ (195), 259 (225), 253 (193), $249 \mathrm{~m} \mu$ (sh., 165).

NMR spectrum $\left(\mathrm{CDCl}_{3}\right): \delta \sim 3.0\left(1 \mathrm{H} \mathrm{m}, \mathrm{OH}\right.$; disappeared upon deuteration), $3.77\left(2 \mathrm{H} \mathrm{s}, \mathrm{CH}_{2}\right)$, $4.33\left(2 \mathrm{H} \mathrm{s}, \mathrm{CH}_{2}\right)$ and $\sim 7.35(5 \mathrm{H} \mathrm{m}$, phenyl).

Compound 3 was identical with 1-hydroxy-3-phenyl-2-propane, which was synthesized in three steps from phenylacetic acid according to the procedure of FisHer and HIBBERT ${ }^{8}$.

(b) Isolation of L-Leucine and 2a. The aqueous layer was evaporated and chromatographed on a column of cellulose powder ( $300 \mathrm{~g}$ ) with Solvent system B. A mixture of a starting material having $\mathrm{Rf} \sim 0.7$ and leucine having $\mathrm{Rf} 0.58$ (Mixture $\mathrm{A}$ ) and a mixture of leucine and the substance $\mathbf{2 a}$ having $\mathrm{Rf} 0.53$ (Mixture B) were eluted in the fractions of $540 \sim 730$ and $730 \sim 890 \mathrm{ml}$, respectively. Mixture A (160 mg) was rehydrolyzed with hydrochloric acid. Mixture B $(500 \mathrm{mg})$ was dissolved in a minimal quantity of $0.1 \mathrm{~N}$ aqueous ammonia and chromatographed on a column of Amberlite CG-50 ( $\mathrm{H}$ form. $20 \times 170 \mathrm{~mm}$ ) with water. The ninhydrin-positive fraction $(45 \sim 85 \mathrm{ml})$ containing leucine was evaporated to give crystals $(110 \mathrm{mg})$. Recrystallization from $70 \%$ aqueous ethanol gave colorless plates of L-leucine; yield $85 \mathrm{mg} ; \mathrm{mp}>250^{\circ} \mathrm{C}$ (dec.) (sublimed at $\sim 145^{\circ} \mathrm{C}$ ), $[\mathrm{M}]_{\mathrm{D}}^{27}-14.1^{\circ}$ (c 0.93, water), $[\mathrm{M}]_{\mathrm{D}}^{27}+19.5^{\circ}\left(c 0.85,5 \mathrm{~N}\right.$ hydrochloric acid). Lit. ${ }^{3 b)}:[\mathrm{M}]_{\mathrm{D}}^{25}-14.4^{\circ}(c 2$, water $),[\mathrm{M}]_{\mathrm{D}}^{25}+21.0^{\circ}(c 2$, $5 \mathrm{~N}$ hydrochloric acid).

Found: C 54.86, H 10.02, N 10.57\%. Calcd. for $\mathrm{C}_{6} \mathrm{H}_{13} \mathrm{NO}_{2}$ : C 54.94, H 9.99, N $10.68 \%$.

The physicochemical properties of this substance were identical with those of an authentic sample of L-leucine.

Next, the RYDON-SMITH - positive fraction $(130 \sim 210 \mathrm{ml})$ containing $2 \mathrm{a}$ was evaporated to give a solid ( $370 \mathrm{mg})$, which was chromatographed on a column of Dowex $1 \times 2(\mathrm{OH}$ form, $15 \times 110 \mathrm{~mm}$ ). Water $(40 \mathrm{ml})$ eluted impurities; subsequent elution with $0.1 \mathrm{~N}$-hydrochloric acid gave $2 \mathrm{a}$ in fraction $60 \sim 120 \mathrm{ml}$, which was reprecipitated from methanol - ethyl ether to give a colorless monohydrochloride-monohydrate; yield $340 \mathrm{mg} ; \mathrm{mp} 192 \sim 193^{\circ} \mathrm{C}$ (dec.), $[\alpha]_{\mathrm{D}}^{17}+26.8^{\circ}$ (c 0.82 , acetic acid); $\mathrm{pKa}<4$, $5.6,>13$ (in $60 \%$ aqueous dimethylformamide).

Found: C 49.36, H 6.36, N 15.62, Cl 6.74\%. Calcd. for $\mathrm{C}_{22} \mathrm{H}_{32} \mathrm{~N}_{6} \mathrm{O}_{6} \cdot \mathrm{HCl} \cdot \mathrm{H}_{2} \mathrm{O}: \mathrm{C}$ 49.76, H 6.64, N 15.82, Cl $6.67 \%$.

IR spectrum: $\sim 3350,3100(\mathrm{NH}), 2960(\mathrm{CH}), 2600(\mathrm{NH}), \sim 1730(\mathrm{COOH}), 1680 \sim 1620$ (guanidinium and ureide and amide I), 1560 (amide II), 760,740,700 $\mathrm{cm}^{-1}$ (phenyl).

NMR spectrum $\left(\mathrm{CF}_{3} \mathrm{COOD}\right): \delta 1 \sim 1.05\left[6 \mathrm{H} \mathrm{m},\left(\mathrm{CH}_{3}\right)_{2} \mathrm{CH}\right.$ (in Leu)], $\sim 1.85\left[3 \mathrm{H} \mathrm{m}, \mathrm{CH}_{2}\right.$ and $\mathrm{CH}$ (in Leu)], $\sim 2.05$ [2H m, $\mathrm{CH}_{2}$ (in 4a)], $\sim 3.3\left[2 \mathrm{H} \mathrm{m}, \mathrm{CH}_{2}\right.$ (in Phe)], $\sim 3.45\left[2 \mathrm{H} \mathrm{m}, \mathrm{CH}_{2}\right.$ (in 4a)], 3.9 $[1 \mathrm{H} \mathrm{m}, \beta-\mathrm{CH}$ (in $4 \mathrm{a})], 4.6 \sim 5.0$ [3H m, three $\alpha$-methines], $7.1 \sim 7.4[5 \mathrm{H} \mathrm{m}$, phenyl (in Phe)]. On irradiation at $\delta 4.83$, a multiplet at $\delta 3.27$ collapsed to an $\mathrm{AB}$ quartet $(\mathrm{J} \sim 14 \mathrm{~Hz})$ with changes in the multiplets at $\delta \sim 3.9$ and $\sim 1.85$. Irradiation at $\delta 2.05$ caused multiplets at $\delta \sim 3.95$ and $\sim 3.5$ to col- 
lapse to a doublet $(\mathrm{J} \sim 7 \mathrm{~Hz})$ and an $\mathrm{AB}$ quartet $(\mathrm{J} \sim 14 \mathrm{~Hz})$, respectively, with change of multiplets at $\delta \sim 1.05$ into singlets.

UV spectrum: $\lambda_{\mathrm{max}}^{\mathrm{AcOH}}(\varepsilon) 267(130), 264(200), 258(265), 253 \mathrm{~m} \mu(245)$.

The C-terminal amino acid analysis of $\mathbf{2 a}$ gave phenylalanine and leucine. However, crude $\mathbf{2 a}$ gave isoleucine in addition to phenylalanine and leucine in the molar ratio $1.0: 5.3: 11.6$. The low value for phenylalanine can probably be attributed to a ureido bond in constituent 1 resistant to hydrazinolysis.

(c) Isolation of L-Valine and $\mathbf{2 b}$ : From the above cellulose chromatography column (in b), a mixture of valine having $\operatorname{Rf} 0.52$ and substance $2 b$ having $\operatorname{Rf} 0.51$ (Mixture $C$ ) was subsequently eluted in the fraction between $890 \sim 970 \mathrm{ml}$. This mixture $(60 \mathrm{mg})$ was chromatographed on a column of Amberlite CG-50 (H form, $12 \times 95 \mathrm{~mm}$ ) with water as described above. The ninhydrin-positive fraction $(10 \sim 26 \mathrm{ml})$ was evaporated to give colorless plates of L-valine which were recyrstallized from $80 \%$ aqueous ethanol; yield $12 \mathrm{mg} ; \mathrm{mp}>250^{\circ} \mathrm{C},[\mathrm{M}]_{\mathrm{D}}^{26}+33.0^{\circ}(c 0.55,5 \mathrm{~N}$ hydrochloric acid $),[\mathrm{M}]_{\mathrm{D}}^{28}$ $+70.5^{\circ}\left(c 0.57\right.$, acetic acid). Lit. $^{3 d}:[\mathrm{M}]_{1}^{25}+33.1^{\circ}$ (5 N hydrochloric acid), $[\mathrm{M}]_{v}^{25}+72.0^{\circ}$ (acetic acid).

Found: C 51.19, H 9.56, N $11.90 \%$. Calcd. for $\mathrm{C}_{5} \mathrm{H}_{11} \mathrm{NO}_{2}$ : C $51.26, \mathrm{H} 9.47, \mathrm{~N} 11.96 \%$.

The physicochemical properties of this substance were identical with those of an authentic sample of L-valine.

The subsequent fraction $(33 \sim 72 \mathrm{ml})$ positive to RYDON-SMITH containing $\mathbf{2 b}$ was evaporated to give a solid ( $39 \mathrm{mg}$ ), which was chromatographed on a column of Dowex $1 \times 2$ (OH form, $5.5 \times 60 \mathrm{~mm}$ ) with water $(2 \mathrm{ml})$ and successively with $0.1 \mathrm{~N}$ hydrochloric acid. The fraction $(2.5 \sim 4 \mathrm{ml})$ containing 2b was evaporated to a solid which was precipitated from methanol - ethyl ether to give a colorless monohydrochloride-monohydrate; yield $31 \mathrm{mg} ; \mathrm{mp} \sim 173^{\circ} \mathrm{C}\left(\mathrm{dec}\right.$ ), $[\alpha]_{\mathrm{D}}^{20}+28.0^{\circ}$ (c 1.0, acetic acid); $\mathrm{pKa}<4,5.5,>13$ (in $60 \%$ aqueous dimethylformamide).

Found: C 48.39, H 6.07, N 15.90, Cl 6.49\%. Calcd. for $\mathrm{C}_{21} \mathrm{H}_{30} \mathrm{~N}_{6} \mathrm{O}_{6} \cdot \mathrm{HCl} \cdot \mathrm{H}_{2} \mathrm{O}: \quad \mathrm{C} 48.79, \mathrm{H}$ $6.43, \mathrm{~N} 16.25, \mathrm{Cl} 6.86 \%$.

IR spectrum: $\sim 3350,3100(\mathrm{NH}), 2960(\mathrm{CH}), 2600(\mathrm{NH}), \sim 1720(\mathrm{COOH}), 1680 \sim 1620$ (guanidinium, ureide and amide I), 1550 (amide II), 760, 740, $700 \mathrm{~cm}^{-1}$ (phenyl).

NMR spectrum $\left(\mathrm{CF}_{3} \mathrm{COOD}\right): \delta 1.06$ and 1.08 [each $3 \mathrm{H} \mathrm{d},\left(\mathrm{CH}_{3}\right)_{2} \mathrm{CH}$ (in Val)], $1.7 \sim 2.2[2 \mathrm{H} \mathrm{m}$, $\mathrm{CH}_{2}$ (in 4a)], 2.2 $2.55(1 \mathrm{H} \mathrm{m}, \mathrm{CH}$ (in Val)], 3.13 and 3.36 [each $1 \mathrm{H} \mathrm{q}, \mathrm{J} \sim 14.5$ and $8 \mathrm{~Hz}$ and $\mathrm{J} \sim 14.5$ and $\sim 5.5 \mathrm{~Hz}$, respectively, forming the $\mathrm{AB}$ part of an $\mathrm{ABX}$ system (in Phe)], $3.3 \sim 3.7\left[2 \mathrm{H} \mathrm{m}, \mathrm{CH}_{2}\right.$ (in 4a)], $\sim 3.9[1 \mathrm{H} \mathrm{m}, \beta-\mathrm{CH}$ (in 4a)], $4.61[1 \mathrm{H} \mathrm{d}, \mathrm{J} 5 \mathrm{~Hz}, \alpha-\mathrm{CH}$ (in Val)], $\sim 4.8[1 \mathrm{H} \mathrm{m}, \alpha-\mathrm{CH}$ (in Phe)], $\sim 4.9[1 \mathrm{H} \mathrm{m}, \alpha-\mathrm{CH}$ (in 4a)], 7.3 [5H m, phenyl (in Phe)]. On irradiation at $\delta 2.42$ a doublet at $\delta 4.61$ and doublets at $\delta \sim 1.07$ collapsed to singlets. Irradiation at $\delta 3.28$, caused the multiplet at $\delta \sim 4.8$ to collapse to a singlet. Irradiation at $\delta 3.95$, caused a multiplet at $\delta \sim 4.9$ to collapse to a singlet.

UV spectrum: $\lambda_{\mathrm{max}}^{\mathrm{Ac} \text { OH }}(\varepsilon) 267$ (135), 264 (205), 258 (265), $253 \mathrm{~m} \mu(245)$

The C-terminal analysis of $\mathbf{2 b}$ gave phenylalanine and valine.

(d) Isolation of 1: From the above cellulose chromatography column (in b), the substance 1 having $\operatorname{Rf} 0.25$ was eluted in the fraction between $1,035 \sim 1,500 \mathrm{ml}$, together with ammonium chloride (Mixture D). This mixture ( $740 \mathrm{mg}$ ) was chromatographed on a column of Amberlite CG-50 [H form] to give a solid $(170 \mathrm{mg})$ which was treated with Dowex $1 \times 2(\mathrm{OH}$ form) as in the isolation of $\mathbf{2 a}$ or $\mathbf{2 b}$. Substance 1 was obtained as a colorless monohydrochloride-monohydrate; yield $152 \mathrm{mg}$; mp 216 $220^{\circ} \mathrm{C}(\mathrm{dec}) ;[\alpha]_{589}^{11}+33^{\circ},[\alpha]_{548}^{11}+39^{\circ},[\alpha]_{436}^{11}+73^{\circ},[\alpha]_{405}^{11}+93^{\circ},[\alpha]_{365}^{11}+128^{\circ}$ (c 1.5, water); pKa $<3,3.9,>12$ (in water).

Found: C 46.06, H 5.64, N 16.66, Cl 8.72\%. Calcd. for $\mathrm{C}_{16} \mathrm{H}_{21} \mathrm{~N}_{5} \mathrm{O}_{5} \cdot \mathrm{HCl} \cdot \mathrm{H}_{2} \mathrm{O}: \quad \mathrm{C} 45.99$, H 5.79, N 16.76, Cl $8.48 \%$.

Mol. wt. (vapor pressure osmometer): approximately 400. Calcd. for the monohydrochloride: 399.85 .

IR spectrum: 3380, $\sim 3100(\mathrm{NH}), 2950(\mathrm{CH}), \sim 2500(\mathrm{NH}), 1725(\mathrm{COOH}), 1680, \sim 1650$ (guanidinium and ureide), $1570(\mathrm{NH}), 750,710 \mathrm{~cm}^{-1}$ (phenyl).

NMR spectrum $\left(\mathrm{D}_{2} \mathrm{O}\right.$; Fig. 4): $\delta 1.4 \sim 2.1\left[2 \mathrm{H} \mathrm{m}, \mathrm{CH}_{2}\right.$ (in 4a)], 2.97 and 3.19 [each $1 \mathrm{H} \mathrm{q}, \mathrm{J} 14$ and $8.5 \mathrm{~Hz}$, and $\mathrm{J} 14$ and $5.5 \mathrm{~Hz}$, respectively, forming the $\mathrm{AB}$ part of an $\mathrm{ABX}$ system, $\mathrm{CH}_{2}$ (in Phe)], 3.33 [ $2 \mathrm{H} \mathrm{m}, \mathrm{CH}_{2}$ (in 4a)], $3.80(1 \mathrm{H} \mathrm{m}, \beta-\mathrm{CH}$ (in 4a)], $4.28(1 \mathrm{H} \mathrm{d}, \mathrm{J} 6 \mathrm{~Hz}, \alpha-\mathrm{CH}$ (in 4a)], 4.40 [1 $1 \mathrm{H} \mathrm{q}, \mathrm{J} 8$ and $5 \mathrm{~Hz}, \alpha-\mathrm{CH}$ (in Phe)], 7.35 [5H m, phenyl (in Phe)]. On irradiation at $\delta 1.83$ the multiplets at $\delta 3.33$ 
and 3.80 collapsed to an $\mathrm{AB}$ quartet $(\mathrm{J} \sim 13 \mathrm{~Hz})$ and a doublet $(\mathrm{J} \sim 6 \mathrm{~Hz})$, respectively. Irradiation at $\delta 3.80$, caused a doublet at $\delta 4.28$ to collapse to a singlet.

NMR spectrum (dimethylsulfoxide- $\mathrm{d}_{6}$ ): $\delta 1.75\left[2 \mathrm{H} \mathrm{m}, \mathrm{CH}_{2}\right.$ (in 4)], $3.05\left[2 \mathrm{H} \mathrm{m}, \mathrm{CH}_{2}\right.$ (in Phe)], $3.3\left[2 \mathrm{H} \mathrm{m}, \mathrm{CH}_{2}\right.$ (in 4)], $3.8[1 \mathrm{H} \mathrm{m}, \beta-\mathrm{CH}$ (in 4)], 4.4 [2 $\mathrm{H} \mathrm{m}$, two $\alpha$-methines (in 4 and Phe)], 6.57 and 6.92 [each $1 \mathrm{H} \mathrm{d}, \alpha-\mathrm{NH}$ (in 4 and $\mathrm{Phe}$ )], 7.14 [ $\sim 1 \mathrm{H}$ broad s, $>\mathrm{C}=\mathrm{NH}$ (in 4)], $7 \sim 7.5[5 \mathrm{H} \mathrm{m}$, phenyl (in Phe)], 7.76 and 8.29 [each $1 \mathrm{H}$ broad s, $\mathrm{NH}-3$ and $\mathrm{NH}-1$ respectively (in 4)], $12 \sim 13(\sim 1 \mathrm{H} \mathrm{m}, \mathrm{COOH}$ ).

UV spectrum: $\lambda_{\max }^{\mathrm{H}_{2} \mathrm{O}}(\varepsilon) 267$ (145), 264 (200), 258 (250), 253 (215), $247 \mathrm{~m} \mu$ (175).

The C-terminal analysis of $\mathbf{1}$ gave only phenylalanine as an amino acid; the constituent $\mathbf{4 a}$ was assumed to be deomposed by hydrazine.

Acid Hydrolysis of 1 (Isolation of DL-Phenylalanine and 4). A solution of $1(300 \mathrm{mg})$ in $1 \mathrm{~N}$ hydrochloric acid $(60 \mathrm{ml})$ was heated at $\sim 145^{\circ} \mathrm{C}$ for 72 hours in a sealed tube and then evaporated. The residue showed, by TLC on a silica gel "Replate" (Solvent system C), two ninhydrin-positive spots of Rf 0.64 and 0.30 and two RYDON-SMrTH - positive spots (minor) of Rf 0.63 and 0.60 . The residue was chromatographed on a column of silica gel (Wako gel, $80 \mathrm{~g}$ ) with Solvent system D. A mixture of phenylalanine (Rf 0.64), 7a (Rf 0.63) and $7 \mathrm{~b}$ (Rf 0.60$)$, and 4 ( Rf 0.30 ) were eluted in this order in the fractions of $130 \sim 250$ and $280 \sim 640 \mathrm{ml}$, respectively. The former fraction was evaporated and the residue $(220 \mathrm{mg}$ ) was chromatographed on a column of Amberlite CG-50 ( $\mathrm{H}$ form, $20 \times 120 \mathrm{~mm}$ ) with water. The fraction $(17 \sim 67 \mathrm{ml})$ of phenylalanine was evaporated and the residual solid was recrystallized from water to give colorless plates of DL-phenylalanine; yield $87 \mathrm{mg} ; \mathrm{mp}>250^{\circ} \mathrm{C}$ (dec.), $[\alpha]_{0}^{27} 0^{\circ}(c 0.82$, water $)$.

Found: C 65.41, H 6.84, N 8.30\%. Calcd. for $\mathrm{C}_{9} \mathrm{H}_{11} \mathrm{NO}_{2}$ : C $65.44, \mathrm{H} 6.71, \mathrm{~N} 8.48 \%$.

The physicochemical properties of the substance were identical with those of authentic DL-phenylalanine.

The fraction $(75 \sim 225 \mathrm{ml})$ containing $7 \mathbf{a}$ and $7 \mathbf{b}$ was evaporated and the residue $(95 \mathrm{mg})$ was separated into $7 \mathbf{a}(30 \mathrm{mg})$ and $7 \mathbf{b}(21 \mathrm{mg})$ by cellulose and Dowex $1 \times 2(\mathrm{OH}$ form) column chromatography as will be described in the preparation of $7 \mathbf{a}$ and $7 \mathbf{b}$ from 1 .

From the above silica gel column, the fraction containing 4 was evaporated and the residue $(100 \mathrm{mg})$ was chromatographed on a column of Dowex $1 \times 2(\mathrm{OH}$ form, $10 \times 200 \mathrm{~mm})$ with water. The ninhydrin-positive fraction $(27 \sim 42 \mathrm{ml})$ was evaporated to give colorless crystals of the free base of 4 ; yield $51 \mathrm{mg} ; \mathrm{mp} \sim 240^{\circ} \mathrm{C}$ (dec.); $\mathrm{pKa}<2,7.5,>12$ (in water).

The molar optical rotations of 4 are shown in Table 1.

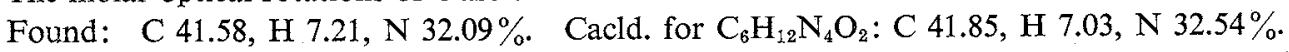

IR spectrum: dihydrochloride: $\sim 3400(\mathrm{NH}), \sim 2950(\mathrm{CH}), \sim 1740(\mathrm{COOH}), 1675,1620$ (guanidinium), $\sim 1600,1500 \mathrm{~cm}^{-1}(\mathrm{NH})$.

NMR spectrum $\left(\mathrm{D}_{2} \mathrm{O}\right.$ and 1 equivalent $\left.\mathrm{DCl}\right): \delta 1.8 \sim 2.4\left(2 \mathrm{H} \mathrm{m}, \mathrm{CH}_{2}\right), \sim 3.5\left(2 \mathrm{H} \mathrm{m}, \mathrm{CH}_{2}\right), 4.05 \sim$ $4.35(2 \mathrm{H} \mathrm{m}, \alpha-\mathrm{CH}$ and $\beta-\mathrm{CH})$.

Isolation of $4 \mathrm{a}$ and $4 \mathrm{~b}$. A sample of $(46 \mathrm{mg}, 0.27 \mathrm{mmol})$ of 4 was dissolved in a hot aqueous solution $(4.5 \mathrm{ml})$ of flavianic acid dihydrate $(200 \mathrm{mg}, 0.57 \mathrm{mmol})$ and the solution was allowed to stand at room temperature. The resulting crystals $(153 \mathrm{mg})$ were filtered, washed, and repeatedly recrystallized from water $(2.8 \mathrm{ml}$ and $1.2 \mathrm{ml})$ to give yellow prisms of the diflavianate of $4 \mathrm{a}$; yield $102 \mathrm{mg}$; mp $199 \sim 202^{\circ} \mathrm{C}$ (dec.).

Table 1. Molar optical rotations of $4,4 \mathrm{a}, 4 \mathrm{~b}$ and capreomycidine (Cap.) in water, water and 1 eq. $\mathrm{HCl}$, water and 2 eq. $\mathrm{HCl}$, and $6 \mathrm{~N} \mathrm{HCl}$

\begin{tabular}{l|c|c|c|c|c|c|c|c}
\hline \multirow{2}{*}{ Solvent } & \multicolumn{4}{|c|}{$[\mathrm{M}]_{589}^{25}{ }^{\circ}(c \sim 0.75)$} & \multicolumn{4}{c}{$[\mathrm{M}]_{365}^{25}{ }^{\circ}(c \sim 0.75)$} \\
\cline { 2 - 9 } & 4 & $4 \mathrm{a}$ & $4 \mathrm{~b}$ & Cap. & 4 & $4 \mathrm{a}$ & $4 \mathrm{~b}$ & Cap. \\
\hline $\mathrm{H}_{2} \mathrm{O}$ & +37.8 & +35.9 & +37.2 & -41.3 & +132 & +138 & +120 & -129 \\
$\mathrm{H}_{2} \mathrm{O}+1$ eq. $\mathrm{HCl}$ & -19.6 & -11.9 & -39.4 & +32.5 & -56.6 & -10.5 & -133 & +127 \\
$\mathrm{H}_{2} \mathrm{O}+2$ eq. $\mathrm{HCl}$ & -25.3 & -7.5 & -44.6 & +45.9 & -73.4 & +2.5 & -158 & +170 \\
$6 \mathrm{~N} \mathrm{HCl}$ & -21.1 & +18.4 & -65.0 & +67.1 & -60.8 & +92.6 & -223 & +238 \\
\hline
\end{tabular}


Found: C 38.78, H 3.46, N 13.67, S 7.82\%. Calcd. for $\mathrm{C}_{6} \mathrm{H}_{12} \mathrm{~N}_{4} \mathrm{O}_{2} \cdot 2 \mathrm{C}_{10} \mathrm{H}_{6} \mathrm{~N}_{2} \mathrm{O}_{8} \mathrm{~S}: \quad$ C 39.00 , H 3.02, N 13.99, S $8.01 \%$.

IR spectrum: $3400 \sim 3000(\mathrm{NH}), \sim 2900(\mathrm{CH}), \sim 2500(\mathrm{NH}), 1745(\mathrm{COOH}), 1680,1625$ (guanidinium), 1585, $\sim 1350\left(\mathrm{NO}_{2}\right), \sim 1200,1035\left(\mathrm{SO}_{2}\right), 820,785,705 \mathrm{~cm}^{-1}$ (phenyl).

The diflavianate of $\mathbf{4 a}$ is sparingly soluble in water but insoluble in organic solvents.

A solution of the diflavianate of $4 \mathrm{a}(102 \mathrm{mg})$ in $6 \mathrm{~N}$ hydrochloric acid $(10 \mathrm{ml})$ was extracted three times with benzene (each $3 \mathrm{ml}$ ) and evaporated to give the hydrochloride of $4 \mathbf{a}$, which was passed through a short column of Dowex $1 \times 2(\mathrm{OH}$ form) with water. The fraction $(\mathrm{pH} 8 \sim 9)$ containing $4 \mathrm{a}$ was evaporated to give the free base monohydrate; colorless needles; $20 \mathrm{mg} ; \mathrm{mp} 251^{\circ} \mathrm{C}$ (dec.); $\mathrm{pKa}<2,7.5$, $>12$ (in water).

The molar optical rotations of $\mathbf{4 a}$ are shown in Fig. 3 and Table 1.

Found: C 38.01, H 7.27, N 29.79\%. Calcd. for $\mathrm{C}_{6} \mathrm{H}_{12} \mathrm{~N}_{4} \mathrm{O}_{2} \cdot \mathrm{H}_{2} \mathrm{O}: \quad$ C 37.89, H 7.42, N $29.46 \%$.

NMR spectrum $\left(\mathrm{D}_{2} \mathrm{O}\right.$ and 1 equivalent DCl; Fig. 1$): \delta \sim 2.05\left(2 \mathrm{H} \mathrm{m}, \mathrm{CH}_{2}\right), \sim 3.5\left(2 \mathrm{H} \mathrm{m}, \mathrm{CH}_{2}\right)$, $4.11(1 \mathrm{H} \mathrm{d}, \mathrm{J} \sim 5 \mathrm{~Hz}, \alpha-\mathrm{CH}), 4.19(1 \mathrm{H} \mathrm{m}, \beta-\mathrm{CH})$. On irradiation at $\delta 2.05$, the multiplets at $\delta \sim 3.5$ and 4.19 collapsed to an $\mathrm{AB}$ quartet $(\mathrm{J} 13 \mathrm{~Hz}$ ) and a doublet $(\mathrm{J} 5 \mathrm{~Hz}$ ) respectively. On simultaneous irradiation at $\delta 3.43$ and 4.19, a multiplet at $\delta \sim 2.05$ collapsed to an $\mathrm{AB}$ quartet $(\mathrm{J} \sim 13 \mathrm{~Hz})$.

The filtrates and washings from isolation of $\mathbf{4 a}$ diflavianate were combined and evaporated to a yellow residue $(115 \mathrm{mg})$, which was repeatedly recrystallized from water $(0.8 \mathrm{ml}$ and $0.7 \mathrm{ml})$ to give yellow prisms of $4 \mathrm{~b}$ diflavianate; yield $94 \mathrm{mg} ; \mathrm{mp} 213 \sim 220^{\circ} \mathrm{C}$ (dec.), $[\alpha]_{\mathrm{D}}^{20}-5.6^{\circ}$ (c 1.0, water).

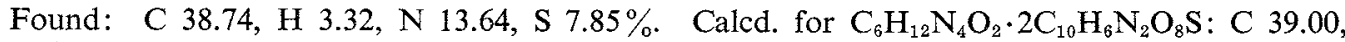
H $3.02, \mathrm{~N} 13.99$, S $8.01 \%$.

IR spectrum: $3400 \sim 3010(\mathrm{NH}), \sim 2900(\mathrm{CH}), \sim 2500(\mathrm{NH}), \sim 1750(\mathrm{COOH}), 1680,1640,1625$ (guanidinium), 1580, 1350 $\left(\mathrm{NO}_{2}\right), \sim 1225,1035\left(\mathrm{SO}_{2}\right), 820,785,705 \mathrm{~cm}^{-1}$ (phenyl).

This flavianate is soluble in water but insoluble in organic solvents.

Capreomycidine similarly gave a diflavianate which was recrystallized from water to give yellow prisms; mp $213 \sim 220^{\circ} \mathrm{C}$ (dec.), $[\alpha]_{D}^{20}+5.6^{\circ}$ ( c 1.0, water). The IR spectrum ( $\mathrm{KBr}$ ) was completely superimposable on that of the diflavianate of $\mathbf{4 b}$.

The flavianate of $4 \mathrm{~b}(94 \mathrm{mg})$ was treated with $6 \mathrm{~N}$ hydrochloric acid followed by column chromatography with Dowex $1 \times 2$ (OH form) to give colorless needles of the free base of $4 \mathrm{~b} ; 17 \mathrm{mg} ; \mathrm{mp} 241^{\circ} \mathrm{C}$ (dec.); $\mathrm{pKa}<2,7.5,>12$ (in water).

The molar optical rotations of $4 \mathrm{~b}$ are shown in Fig. 2 and Table 1.

Found: $\mathrm{C} 41.38, \mathrm{H} 6.98, \mathrm{~N} 32.18 \%$. Calcd. for $\mathrm{C}_{6} \mathrm{H}_{12} \mathrm{~N}_{4} \mathrm{O}_{2}: \quad \mathrm{C} 41.85, \mathrm{H} 7.03, \mathrm{~N} 32.54 \%$.

NMR spectrum ( $\mathrm{D}_{2} \mathrm{O}$ and 1 equivalent $\mathrm{DCl}$; Fig. 1$): \delta \sim 2.18\left(2 \mathrm{H} \mathrm{m}, \mathrm{CH}_{2}\right), \sim 3.5\left(2 \mathrm{H} \mathrm{m}, \mathrm{CH}_{2}\right)$, $4.16(1 \mathrm{H} \mathrm{d}, \mathrm{J} \sim 5 \mathrm{~Hz}, \alpha-\mathrm{CH}), 4.23(1 \mathrm{H} \mathrm{m}, \beta-\mathrm{CH})$. On irradiation at $\delta 2.18$, the multiplets at $\delta \sim 3.5$ and 4.23 collapsed to an $\mathrm{AB}$ quartet $(\mathrm{J} \sim 13 \mathrm{~Hz}$; a singlet in appearance) and a doublet $(\mathrm{J} \sim 5 \mathrm{~Hz})$, respectively. Simultaneous irradiation at $\delta 3.50$ and 4.23 , caused a multiplet at $\delta \sim 2.18$ to collapse to an $\mathrm{AB}$ quartet $(\mathrm{J} \sim 14 \mathrm{~Hz})$.

By similar treatment the diflavianate of capreomycidine gave colorless needles of the free base. The physicochemical prperties of capreomycidine (NMR spectrum: Fig. 1), except for the sign of optical rotations (Fig. 2 and Table 1), were in fair agreement with those of $\mathbf{4 b}$.

Substance 4 could also be fractionally crystallized as the monopicrate to give equal amounts of crystalline $4 \mathrm{a}$ and $\mathbf{4 b}$. The monopicrate of $4 \mathrm{a}$ was obtained as crystalline yellow plates; $\mathrm{mp} \sim 210^{\circ} \mathrm{C}$ (dec.), but that of $4 \mathbf{b}$ could not be crystallized.

Preparation of 5 . To a solution of free base $4(40 \mathrm{mg})$ in dry methanol $(4 \mathrm{ml})$, acetic anhydride ( $2 \mathrm{ml}$ ) was added and the solution was allowed to stand at room temperature for 10 hours. Cellulose TLC (Solvent system E) showed that the starting material (Rf 0.10 ) had been replaced by a new spot (5, Rf 0.51). The reaction mixture was evaporated and the residual solid (64 $\mathrm{mg}$ ) was chromatographed on a column of cellulose powder $(15 \mathrm{~g})$ with Solvent system F. Solvent systems containing ethanol and butanol could not be utilized for chromatography of 5 because they caused ester exchange. The fraction $(65 \sim 180 \mathrm{ml})$ containing 5 was evaporated to give a very hygroscopic solid; yield $59 \mathrm{mg}(95 \%)$; $[\alpha]_{D}^{15}+17.5^{\circ}$ (c 1.0, methanol).

Found: C 45.49, H 7.23, N 19.15\%. Calcd. for $\mathrm{C}_{11} \mathrm{H}_{18} \mathrm{~N}_{4} \mathrm{O}_{4} \cdot \mathrm{H}_{2} \mathrm{O}$ (mol. wt. 270.29): C 45.82, 
H $6.99, \mathrm{~N} 19.44 \%$.

Mass spectrum $(m / e): 228$ (high resolution mass: $\left.228.1215 ; \mathrm{M}^{+}-\mathrm{CH}_{2}=\mathrm{C}=\mathrm{O}\right), 197,185,169$, $149,138,137,127,110,98$.

IR spectrum: $\sim 3300(\mathrm{NH}), \sim 2900(\mathrm{CH}), \sim 1735$ (ester), 1665, 1635 (guanidine and amide I), $1540 \mathrm{~cm}^{-1}$ (amide II).

NMR spectrum (methanol- $\left.\mathrm{d}_{4}\right): \delta \sim 1.89(3 \mathrm{H} \mathrm{s}, \mathrm{N}-\mathrm{Ac}), 2.00$ and 2.03 [each $1.5 \mathrm{H}(3 \mathrm{H}$ in total) s, $\mathrm{N}-\mathrm{Ac}], \sim 2.0\left(2 \mathrm{H} \mathrm{m}, \mathrm{CH}_{2}\right), \sim 3.35\left(2 \mathrm{H} \mathrm{m}, \mathrm{CH}_{2}\right), 3.76\left(3 \mathrm{H} \mathrm{s}, \mathrm{COOCH}_{3}\right), \sim 3.9(1 \mathrm{H} \mathrm{m}, \beta-\mathrm{CH}), 4.65$ and 4.67 [each $0.5 \mathrm{H}(1 \mathrm{H}$ in total) $\mathrm{d}, \mathrm{J} \sim 8 \mathrm{~Hz}$ and $\mathrm{J} 5.5 \mathrm{~Hz}$ respectively, $\alpha-\mathrm{CH})$. On irradiation at $\delta 3.91$, doublets at $\delta 4.65$ and 4.67 collapsed to singlets respectively.

Capreomycidine gave a hygroscopic di- $N$-acetyl-mono- $O$-methyl ester derivative.

IR spectrum: $\sim 3300,3100(\mathrm{NH}), 1750$ (ester), 1675, $\sim 1635$ (guanidine and amide I), $\sim 1555$ $\mathrm{cm}^{-1}$ (amide II).

Mass spectrum $(m / e): 228$ (high resolution mass : $228.1219 ; \mathrm{M}^{+}-\mathrm{CH}_{2}=\mathrm{C}=\mathrm{O}$ ), 197, 185, 169, 149, 138, 137, 127, 110, 98.

Preparation of 6 from 1 . To a stirred solution of $1(140 \mathrm{mg}, 0.385 \mathrm{mmo})$ in $50 \%$ aqueous methanol $(2 \mathrm{ml})$, ethereal diazomethane $(4 \mathrm{ml})$ was slowly added until the solution remained pale yellow. After 30 minutes, cellulose TLC (Solvent system E) of the solution showed that the starting material (Rf 0.30) had disappeared and new compounds of Rf 0.67 (6; major) and $\mathrm{Rf} \sim 0.5$ (7a and $7 \mathbf{b}$; minor) had appeared. In order to prevent 6 from forming a hydantoin, a monohydrochloride was prepared: To the solution was added $1 \mathrm{~N}$ hydrochloric acid $(0.385 \mathrm{ml})$; the resulting solution was evaporated to a pale yellow solid $(170 \mathrm{mg})$, which was chromatographed on a column of cellulose powder $(40 \mathrm{~g})$ with Solvent system E. The fraction $(50 \sim 70 \mathrm{ml})$ containing 6 was evaporated and the residual solid was dissolved in methanol. The solution was treated with active charcoal and evaporated to give a colorless solid; yield $110 \mathrm{mg}(70 \%) ; \mathrm{mp} 160 \sim 161^{\circ} \mathrm{C}$ (dec.).

Found: C 49.10, H 5.91, N 16.58, Cl 8.33\%. Calcd. for $\mathrm{C}_{17} \mathrm{H}_{23} \mathrm{~N}_{5} \mathrm{O}_{5} \cdot \mathrm{HCl}$ : C 49.34, H 5.84, $\mathrm{N} 16.92, \mathrm{Cl} 8.57 \%$.

IR spectrum: $\sim 3350,3100(\mathrm{NH}), 2950(\mathrm{CH}), \sim 2550(\mathrm{NH}), 1735$ (ester), $1720(\mathrm{COOH}), \sim 1660$, 1630 (guanidinium), $1560(\mathrm{NH}), 740,700 \mathrm{~cm}^{-1}$ (phenyl).

NMR spectrum (dimethylsulfoxide- ${ }_{6}$; Fig. 6): $\delta 1.5 \sim 2.0\left[2 \mathrm{H} \mathrm{m}, \mathrm{CH}_{2}\right.$ (in 4a)], $2.8 \sim 3.1[2 \mathrm{H} \mathrm{m}$, $\mathrm{CH}_{2}$ (in Phe)], 3.1 3.4 [2H m, $\mathrm{CH}_{2}$ (in 4a)], 3.60 (3H s, $\mathrm{COOCH}_{3}$ ), $\sim 3.75[1 \mathrm{H} \mathrm{m}, \beta-\mathrm{CH}$ (in 4a)], 4.3

Table 2. Optical rotations of monohydrochlorides of $6,6 \mathbf{a}$ and $6 \mathrm{~b}$ in methanol $\left(c 1.0 ; 17^{\circ} \mathrm{C}\right)$

\begin{tabular}{c|c|c|c|c|c}
\hline Compd. & {$[\alpha]_{589}$} & {$[\alpha]_{546}$} & {$[\alpha]_{436}$} & {$[\alpha]_{405}$} & {$[\alpha]_{365}$} \\
\hline $\mathbf{6}$ & +31.5 & +38.5 & +67.5 & +84.0 & +116 \\
$\mathbf{6 a}$ & +28.5 & +36.0 & +65.0 & +82.0 & +114 \\
$\mathbf{6 b}$ & +7.5 & +9.0 & +17.5 & +22.5 & +39.0 \\
\hline
\end{tabular}

showed a single spot of $\mathrm{Rf} 0.53$.

Synthesis of the Isocyanate of L-Phenylalanine Methyl Ester. The monohydrochloride of L-phenylalanine methyl ester was prepared in the usual way and had $\operatorname{mp} 153 \sim 154^{\circ} \mathrm{C} ;[\alpha]_{\mathrm{D}}^{20}+15^{\circ}(c 1.0, \mathrm{MeOH})$. Through a stirred suspension of the monohydrochloride of L-phenylalanine methyl ester $(6.5 \mathrm{~g})$ in dry toluene $(100 \mathrm{ml})$, a slow stream of phosgene was introduced at $120 \sim 130^{\circ} \mathrm{C}$ under reflux. After 2.5 hours, the resulting clear solution was cooled to about $50^{\circ} \mathrm{C}$. After removal of the solvent, the residual oil was distilled under reduced pressure to give a colorless oil of the isocyanate of L-phenylalanine methyl ester; yield $5.5 \mathrm{~g}(90 \%) ; \mathrm{bp}_{4} 121^{\circ} \mathrm{C} ;[\alpha]_{\mathrm{D}}^{17}-83.3^{\circ}$ (c 2.4, ab. toluene).

Found: C 64.25, H 5.52, N 6.80\%. Calcd. for $\mathrm{C}_{11} \mathrm{H}_{11} \mathrm{NO}_{3}$ : C 64.38, H 5.40, N 6.83\%.

IR spectrum (neat): $3040,2950(\mathrm{CH}), 2250(\mathrm{~N}=\mathrm{C}=\mathrm{O}), 1755$ (ester), $800,750,700 \mathrm{~cm}^{-1}$ (phenyl).

The $\mathrm{D}$-isomer of the isocyanate was also obtained by the method described above; $\mathrm{bp}_{4} 121^{\circ} \mathrm{C}$; $[\alpha]_{\mathrm{D}}^{17}+78.8^{\circ}$ (c 3.3, ab. toluene).

Synthesis of $6 \mathrm{a}$. To a solution of the free base of $4 \mathrm{a}(31.8 \mathrm{mg}, 0.185 \mathrm{mmol})$ in dry dimethylsul- 
foxide $(2 \mathrm{ml})$, a solution of the isocyanate of L-phenylalanine methyl ester $(37.9 \mathrm{mg}, 0.185 \mathrm{mmol})$ in dry dimethylsulfoxide $(0.5 \mathrm{ml})$ was added and the solution was allowed to stand at room temperature for 1 hour. Silica gel TLC (Solvent system E) showed that the starting material (4a; Rf 0.06) disappeared and two new spots of $\mathrm{Rf} 0.53$ (6a; major) and $\mathrm{Rf} 0.62$ (trace) appeared. The solution was evaporated with several additions of toluene to give a residue, which was dissolved in methanol $(1 \mathrm{ml})$. Compound $6 \mathbf{a}$ was converted to the monohydrochloride, to avoid the formation of a hydantoin as described in the synthesis of 6 . To the methanolic solution was added $0.5 \mathrm{~N}$ hydrochloric acid $(0.4 \mathrm{ml})$. The solution was evaporated and the residue was chromatographed on a column of silica gel (Wako gel, $15 \mathrm{~g})$ with the solvent system $\mathrm{E}$. The fraction $(18 \sim 30 \mathrm{ml})$ containing $\mathbf{6 a}$ was evaporated, and the residue was treated with methanol and active charcoal to give a colorless solid of the monohydrochloride of $6 \mathrm{a}$; yield $52 \mathrm{mg}(70 \%) ; \mathrm{mp} 160 \sim 161^{\circ} \mathrm{C}(\mathrm{dec}$.$) . The optical rotations are shown in Fig. 7$ and Table 2.

Found: C 49.21, H 5.90, N 16.87, Cl 8.26\%. Calcd. for $\mathrm{C}_{17} \mathrm{H}_{28} \mathrm{~N}_{5} \mathrm{O}_{5} \cdot \mathrm{HCl}: \quad \mathrm{C} 49.34, \mathrm{H} 5.84$, $\mathrm{N} 16.92, \mathrm{Cl} 8.57 \%$.

Product $6 \mathbf{a}$ was identical with 6 , which was prepared from natural 1 [mixture melting point; optical rotations; IR; NMR (Fig. 6) and TLC].

Synthesis of $6 \mathrm{~b}$. To a solution of the free base of $4 \mathrm{~b}(26.3 \mathrm{mg} ; 0.153 \mathrm{mmol})$ in dry dimethylsulfoxide $(2 \mathrm{ml})$, a solution of the isocyanate of L-phenylalanine methyl ester $(32 \mathrm{mg}, 0.153 \mathrm{mmol})$ in dry dimethylsulfoxide $(0.5 \mathrm{ml})$ was added, and treated as described in the preparation of $6 \mathrm{a}$ to give the monohydrochloride of $\mathbf{6 b}$ as a colorless solid, which showed a single spot of Rf 0.53 on silica gel TLC (Solvent system E); yield $52 \mathrm{mg}(73 \%) ; \mathrm{mp} 153 \sim 155^{\circ} \mathrm{C}$ (dec.). The optical rotations are shown in Fig. 7 and Table 2.

Found: C 49.23, H 5.98, N 16.71, Cl 8.25\%. Caled. for $\mathrm{C}_{17} \mathrm{H}_{23} \mathrm{~N}_{5} \mathrm{O}_{5} \cdot \mathrm{HCl}: \quad \mathrm{C} 49.34, \mathrm{H} 5.84$, N $16.92, \mathrm{Cl} 8.57 \%$.

IR spectrum: $3350, \sim 3100(\mathrm{NH}), 2950(\mathrm{CH}), \sim 2550(\mathrm{NH}), 1740$ (ester), $1720(\mathrm{COOH}), \sim 1670$, 1630 (guanidinium), $1560(\mathrm{NH}), 825,760,700 \mathrm{~cm}^{-1}$ (phenyl).

NMR spectrum (dimethylsulfoxide-d $\mathrm{d}_{6}$; Fig. 6): $\delta 1.3 \sim 2\left[2 \mathrm{H} \mathrm{m}, \mathrm{CH}_{2}\right.$ (in $4 \mathrm{~b}$ )], $\sim 2.95\left[2 \mathrm{H} \mathrm{m}, \mathrm{CH}_{2}\right.$ (in Phe)], $\sim 3.15\left[2 \mathrm{H} \mathrm{m}, \mathrm{CH}_{2}\right.$ (in $\left.\left.4 \mathrm{~b}\right)\right], 3.59\left(3 \mathrm{H} \mathrm{s}, \mathrm{COOCH}_{3}\right), \sim 3.75[1 \mathrm{H} \mathrm{m}, \beta-\mathrm{CH}$ (in $\left.4 \mathrm{~b})\right], \sim 4.31[1 \mathrm{H}$ $\mathrm{m}, \alpha-\mathrm{CH}$ (in 4b)], 4.44 [1H m, $\alpha$-CH (in Phe)], $6.65[1 \mathrm{H} \mathrm{d}, \mathrm{J} \sim 9 \mathrm{~Hz}, \alpha-\mathrm{NH}$ (in 4b)], $6.85[1 \mathrm{H} \mathrm{d}, \mathrm{J} \sim 8 \mathrm{~Hz}$, NH (in Phe)], 7.0 7.4 [6H m, phenyl (Phe) and NH (in 4b)], 7.7, 7.75 and $\sim 8.4$ [each $1 \mathrm{H} \mathrm{m}$, two imino and one carboxyl (?) protons (in $\mathbf{4 b}$ )].

The C-terminal amino acid analyses of $\mathbf{6 a}$ and $\mathbf{6} \mathbf{b}$ gave no amino acids.

Enzymatic Conversion of $\mathbf{6}$ (or $\mathbf{6 a}$ ) and $\mathbf{6 b}$ into $\mathbf{1}$ and $\mathbf{1}^{\prime}$. To a suspension of the monohydrochloride of $6(1.5 \mathrm{mg})$ in water $(0.2 \mathrm{ml}), 1 \% \alpha$-chymotrypsin solution in $0.001 \mathrm{~N}$ hydrochloric acid $(0.02 \mathrm{ml})$ was added; the mixture was neutralized to $\mathrm{pH} 6$ by the addition of $0.05 \mathrm{~N}$ aqueous sodium hydroxide and then digested at $27^{\circ} \mathrm{C}$ for 12 hours. Silica gel TLC (Solvent system E) of the solution showed the appearance of 1 ( $R f$ 0.35) and disappearance of the starting material (0.53). Cellulose TLC (Solvent system $B)$ also showed the regeneration of $1(\operatorname{Rf} 0.25)$ in the reaction.

Synthetic $6 \mathrm{a}$ also gave 1 by the same method.

However, when the monohydrochloride of $\mathbf{6 b}$ was digested with $\alpha$-chymotrypsin, only the isomer $\mathbf{1}^{\prime}$ was formed and this showed a single spot of Rf 0.31 on silica gel TLC (Solvent system E).

In parallel with this experiment, the monohydrochlorides of L-phenylalanine methyl ester and D-phenylalanine methyl ester were digested with $\alpha$-chymotrypsin. The former gave L-phenylalanine, but the latter gave no D-phenylalanine, establishing that the enzyme specifically attacks L-isomer under these conditions.

Preparation of 7a and $7 \mathrm{~b}$ from 1. A solution of monohydrochloride-monohydrate of $1(100 \mathrm{mg})$ in $1 \mathrm{~N}$ hydrochloric acid $(20 \mathrm{ml})$ was heated in a sealed tube at $105 \sim 110^{\circ} \mathrm{C}$ for 24 hours. Cellulose TLC (Solvent system B) of the solution showed that the starting material ( $\mathrm{Rf} 0.25$ ) disappeared and, two new spots (7a, Rf $0.55 ; 7 \mathbf{b}, \mathrm{Rf} 0.48)$ appeared. The solution was evaporated to a residue (110 $\mathrm{mg}$ ), which was chromatographed on a column of cellulose powder $(50 \mathrm{~g})$ with the solvent system $B$. The fraction $(66 \sim 89 \mathrm{ml})$ containing $7 \mathrm{a}$ was evaporated to a solid $(57 \mathrm{mg})$, which was chromatographed on a column of Dowex $1 \times 2(\mathrm{Cl}$ form, $5 \times 40 \mathrm{~mm})$ with water. The fraction containing $7 \mathrm{a}$ was evaporated 
and recrystallized from $50 \%$ aqueous methanol to give colorless plates; yield $37 \mathrm{mg} ; \mathrm{mp}>300^{\circ} \mathrm{C}$ (dec.); $[\alpha]_{589}^{22}+29.5^{\circ} \mathrm{C},[\alpha]_{546}^{22}+33.5^{\circ},[\alpha]_{436}^{22}+56.9^{\circ},[\alpha]_{405}^{22}+67.4^{\circ},[\alpha]_{385}^{22}+90.3^{\circ}$ (c 0.78, acetic acid); pKa 2.9 and $>12$ (in $50 \%$ aqueous methanol).

Found: C 55.63, H 5.58, N 19.97\%. Calcd. for $\mathrm{C}_{16} \mathrm{H}_{19} \mathrm{~N}_{5} \mathrm{O}_{4}$ : C 55.64, H 5.54, N 20.28\%.

IR spectrum: $3300 \sim 3200(\mathrm{NH}), \sim 2900(\mathrm{CH}), 1775$ (CO of a hydantoin ring), $\sim 1720(\mathrm{COOH})$, $1660 \sim 1625, \sim 1575$ (guanidine and ureide), $810,770,700 \mathrm{~cm}^{-1}$ (phenyl).

NMR spectrum $\left(\mathrm{CF}_{3} \mathrm{COOD}\right): \delta 0.8 \sim 1.7\left[2 \mathrm{H} \mathrm{m}, \mathrm{CH}_{2}\right.$ (in 4)], $\sim 3.22\left[2 \mathrm{H} \mathrm{m}, \mathrm{CH}_{2}\right.$ (in 4)], $\sim 3.37$ [2H m, $\mathrm{CH}_{2}$ (in Phe)], $\sim 4.15[1 \mathrm{H} \mathrm{m}, \beta-\mathrm{CH}$ (in 4)], 4.7 5.0 [2H m, two $\alpha$-methines (in 4a and Phe)], $\sim 7.3$ [5H m, phenyl (in Phe)]. Irradiation at $\delta 1.26$, a multiplet at $\delta \sim 4.15$ collapsed to two doublets at $\delta 4.09$ and 4.19 (each $0.5 \mathrm{H}, \mathrm{J} \sim 8 \mathrm{~Hz}$; a triplet in appearance), with a change of a multiplet at $\delta \sim 3.22$. On irradiation at $\delta 4.17$, a multiplet at $\delta 4.7 \sim 5.0$ collapsed to two singlets at $\delta 4.76$ and 4.85 (each $0.5 \mathrm{H}$, $\alpha-\mathrm{CH}$ of 4) and an unchanged multiplet $(1 \mathrm{H}, \alpha-\mathrm{CH}$ of Phe). Irradiation at $\delta 3.37$ caused a multiplet. at $\delta 4.7 \sim 5.0$ to collapse to two singlets at $\delta 4.80$ and 4.87 (each $0.5 \mathrm{H}, \alpha-\mathrm{CH}$ of Phe) and two unchanged doublets at $\delta 4.76$ and 4.85 (each $0.5 \mathrm{H}, \mathrm{J} \sim 8 \mathrm{~Hz}, \alpha-\mathrm{CH}$ of 4).

NMR spectrum (dimethylsulfoxide- $\mathrm{d}_{6}$ ): $\delta \sim 0.8\left[2 \mathrm{H} \mathrm{m}, \mathrm{CH}_{2}\right.$ (in 4)], $2.9\left[2 \mathrm{H} \mathrm{m}, \mathrm{CH}_{2}\right.$ (in 4)], $\sim 3$ [2H m, $\mathrm{CH}_{2}$ (in Phe)], $\sim 3.9[1 \mathrm{H} \mathrm{m}, \beta-\mathrm{CH}$ (in 4)], 4.26 and 4.34 [each $0.5 \mathrm{H} \mathrm{d}, \mathrm{J} \sim 9 \mathrm{~Hz}, \alpha-\mathrm{CH}$ (in 4)], 4.56 and 4.64 [each $0.5 \mathrm{H} \mathrm{t}, \mathrm{J} \sim 4 \mathrm{~Hz}, \alpha-\mathrm{CH}$ (in Phe)], $7.14(>\mathrm{C}=\mathrm{NH}$ in 4 ), $6.9 \sim 7.4$ [5H m, phenyl (in Phe)], 7.49 and 8.36 [each $1 \mathrm{H}$ broad s, NH-3 and $\mathrm{NH}-1$ respectively (in 4)], 8.65 and 8.71 [each $0.5 \mathrm{H}$ broad s, J $<1 \mathrm{~Hz}, \alpha-\mathrm{NH}$ (in Phe)].

UV spectrum: $\lambda_{\mathrm{max}}^{50 \% \mathrm{aq} . \mathrm{MeOH}}(\varepsilon) 263$ (155), 258 (205), $251 \mathrm{~m} \mu$ (195).

The fraction $(89 \sim 115 \mathrm{ml})$ containing $7 \mathrm{~b}$ was also evaporated and purified by the method described above. Recrystallization from $50 \%$ aqueous ethanol gave colorless needles of the monohydrate; yield $13 \mathrm{mg} ; \mathrm{mp} 259^{\circ} \mathrm{C} ;[\alpha]_{588}^{20}+39.1^{\circ},[\alpha]_{548}^{20}+45.3^{\circ},[\alpha]_{436}^{20}+82.6^{\circ},[\alpha]_{405}^{20}+102.3^{\circ},[\alpha]_{385}^{20}+141.2^{\circ}(c 0.86$, $80 \%$ aqueous acetic acid); pKa 3.0 and $>12$ (in $50 \%$ aqueous methanol).

Found: C 52.91, $\mathrm{H} 5.95, \mathrm{~N} 18.94 \%$. Calcd. for $\mathrm{C}_{16} \mathrm{H}_{19} \mathrm{~N}_{5} \mathrm{O}_{4} \cdot \mathrm{H}_{2} \mathrm{O}:$ C 52.89, H 5.83, N $19.27 \%$.

IR spectrum: $3340 \sim 3080(\mathrm{NH}), 2950(\mathrm{CH}), 1775(\mathrm{CO}$ of a hydantoin ring), $\sim 1710(\mathrm{COOH})$, $1675,1655,1605$ (guanidine and ureide), $770,755,700 \mathrm{~cm}^{-1}$ (phenyl).

NMR spectrum $\left(\mathrm{CF}_{3} \mathrm{COOD}\right): \quad \delta 0.6 \sim 1.1\left[1 \mathrm{H} \mathrm{m}\right.$, one proton of $\mathrm{CH}_{2}$ (in 4)], $1.7 \sim 2.1[1 \mathrm{H} \mathrm{m}$, the other proton of $\mathrm{CH}_{2}$ (in 4)], 3.1 3.7 [4H m, two methylenes (in 4 and Phe)], $\sim 4.3[1 \mathrm{H} \mathrm{m}, \beta-\mathrm{CH}$ (in 4)], 4.80 and 4.94 [each $0.5 \mathrm{H} \mathrm{t}$. $\mathrm{J} \sim 5 \mathrm{~Hz}, \alpha-\mathrm{CH}$ (in Phe)], 4.95 and 5.01 [each $0.5 \mathrm{H} \mathrm{d}, \mathrm{J} \sim 3 \mathrm{~Hz}, \alpha-\mathrm{CH}$ (in 4)], $\sim 7.3[5 \mathrm{H} \mathrm{m}$, phenyl (in Phe)]. On irradiation at $\delta 3.32$ (methylenes of 4 and Phe) two triplets at $\delta 4.80$ and 4.94 collapsed to two singlets with changes in the multiplets at $\delta 0.6 \sim 1.1$ and $1.7 \sim 2.1$. On irradiation at $\delta 1.87$ a multiplet at $\delta \sim 4.3$ collapsed to a more resolved multiplet $(\mathrm{J} \sim 3$ and $\sim 10 \mathrm{~Hz}$; a quartet in appearance). On irradiation at $\delta 4.30$ two doublets at $\delta 4.95$ and 5.01 collapsed to two singlets.

NMR spectrum (dimethylsulfoxide- $\mathrm{d}_{6}$ ): $\delta 0.5 \sim 1.3$ and $\sim 1.7$ [each $1 \mathrm{H} \mathrm{m}, \mathrm{CH}_{2}$ (in 4)], 3.0 3.3 [4H m, two methylenes (in 4 and Phe)], $4.0[1 \mathrm{H} \mathrm{m}, \beta-\mathrm{CH}$ (in 4)], $\sim 4.55[2 \mathrm{H} \mathrm{m}$, two $\alpha$-methines (in 4 and Phe)], 7.0 7.5 [5H m, phenyl (in Phe)], 7.32 ( $>\mathrm{C}=\mathrm{NH}$ in 4), 7.38 and 7.48 (each $0.5 \mathrm{H}$ broad s, N-3 (in 4)], 8.28 and 8.37 [each $0.5 \mathrm{H}$ broad s, $\mathrm{N}-1$ (in 4)], 8.60 and 8.62 [each $0.5 \mathrm{H}$ broad s, J $<1 \mathrm{~Hz}, \alpha-\mathrm{NH}$ (in Phe)]. Irradiation at $\delta 4.55$ sharpened two broad singlets at $\delta 8.60$ and 8.62. In the NMR spectrum (DMSO- $\mathrm{d}_{6}$ ) of deuterated $7 \mathrm{~b}$ which was treated with deuterated ammonia, one-proton methine signal ( $\alpha$-CH in Phe) at $\delta \sim 4.55$ disappeared and signals at $\delta 8.60$ and 8.62 changed to sharpened singlets.

UV spectrum: $\lambda_{\mathrm{max}}^{50 \% \mathrm{aq} . \mathrm{MeOH}}(\varepsilon) 263$ (160), $258(205), 251 \mathrm{~m} \mu(200)$.

Also, a solution of $1(1 \mathrm{mg})$ in acetic acid $(0.1 \mathrm{ml})$ was heated in a sealed tube at $125^{\circ} \mathrm{C}$ for $45 \mathrm{minu}$ tes to give only two products $7 \mathbf{a}$ and $7 \mathbf{b}$.

The $C$-terminal amino acid analyses of $7 \mathbf{a}$ and $7 \mathbf{b}$ gave no amino acids.

Partial Conversion between $7 \mathrm{a}$ and $7 \mathrm{~b}$. A solution of $7 \mathrm{a}(50 \mathrm{mg})$ in $1 \mathrm{~N}$ hydrochloric acid $(10 \mathrm{ml})$ was heated in the same manner as in the preparation of $7 \mathrm{a}$ and $7 \mathrm{~b}$ from 1 . Cellulose TLC (Solvent system $B$ ) showed that $7 \mathbf{b}$ ( $R f(0.48)$ was present in addition to $7 \mathbf{a}(\mathrm{Rf} 0.55)$. The solution was evaporated to dryness and the products were purified as described above to give $7 \mathrm{a}(17 \mathrm{mg})$ and $7 \mathrm{~b}(8 \mathrm{mg})$.

The monohydrate of $7 \mathrm{~b}(50 \mathrm{mg})$ treated with $1 \mathrm{~N}$ hydrochloric acid $(10 \mathrm{ml})$ yielded $7 \mathrm{a}(7 \mathrm{mg})$ and $7 \mathrm{~b}$ (18 mg). 
Further Acid Hydrolyses of $7 \mathbf{a}$ and $7 \mathbf{b}$. A solution of $7 \mathbf{a}$ or $7 \mathbf{b}(100 \mathrm{mg})$ in $1 \mathrm{~N}$ hydrochloric acid was heated in a sealed tube at $145^{\circ} \mathrm{C}$ for 48 hours and evaporated to dryness. The resisdue was separated by chromatography, as described for the acid hydrolysate of 1 , to give 4 ( $\sim 15 \mathrm{mg}$ ), DL-phenylalanine $(\sim 20 \mathrm{mg}), 7 \mathrm{a}(\sim 9 \mathrm{mg})$ and $7 \mathbf{b}(\sim 6 \mathrm{mg})$.

Treatment of $7 \mathbf{a}$ and $7 \mathrm{~b}$ with Sodium Hydroxide. A sample of $7 \mathrm{a}(100 \mathrm{mg}, 0.29 \mathrm{mmol})$ was dissolved in $1 \mathrm{~N}$ aqueous sodium hydroxide solution $(0.58 \mathrm{ml}, 0.58 \mathrm{mmol})$ and the solution was allowed to stand at room temperature for 12 hours. Silica gel TLC (Solvent system E) showed that the starting material (Rf 0.54) disappeared and was replaced by two new spots of $\mathrm{Rf} 0.35$ (major) and $\mathrm{Rf} 0.31$ (minor). The mobilities of new spots were identical with those of $\mathbf{1}$ and the isomer $\mathbf{1}^{\prime}$, which were obtained from $6 \mathbf{a}$ (or 6 ) and $\mathbf{6 b}$, respectively, by enzymatic hydrolyses. The solution was neutralized with Amberilite CG-50 (H form) and evaporated to a residue (100 mg), which was chromatographed on a column of Amberlite CG-50 (H-form, $10 \times 50 \mathrm{~mm})$ with water. The fraction $(10 \sim 30 \mathrm{ml})$ containing the substances at $\operatorname{Rf} 0.35$ and $\operatorname{Rf} 0.31$ was evaporated to give a colorless solid; yield $91 \mathrm{mg} ; \mathrm{mp}$ $\sim 208^{\circ} \mathrm{C}$ (dec) $) ;[\alpha]_{D}^{19}+16^{\circ}(c 1.0$, water $)$.

Found: C 52.53, H 9.20, N 18.98\%. Calcd. for $\mathrm{C}_{16} \mathrm{H}_{21} \mathrm{~N}_{5} \mathrm{O}_{5}$ : C 52.89, H 8.83, N 19.27\%.

The solid was considered to be a mixture of isomeric forms of $\mathbf{1}$ and $\mathbf{1}^{\prime}$ (four components in total). However, attempted separations of the mixture were unsuccessful.

The NMR spectrum $\left(\mathrm{D}_{2} \mathrm{O}\right)$ gave complex signais and supported the presence of at least two components : $\delta 1.5 \sim 2.1\left[2 \mathrm{H} \mathrm{m}, \mathrm{CH}_{2}\right.$ (in 4)], $2.7 \sim 3.6$ [4H m, two methylenes (in 4 and Phe)], $3.65 \sim 3.95$ [1H m, $\beta-\mathrm{CH}$ (in 4)], $4.1 \sim 4.6[2 \mathrm{H} \mathrm{m}$, two $\alpha$-methines (in 4 and Phe)], $\sim 7.35$ [5H m, phenyl (in Phe)].

A sample of $7 \mathbf{b}$ treated with 1 equivalent of sodium hydroxide as described above gives the same mixture.

Hydrolysis of 2a. (a) With Hydrochloric Acid: A solution of the monohydrochloride of 2a $(1 \mathrm{mg})$ in $0.1 \mathrm{~N}$ hydrochloric acid $(0.1 \mathrm{ml})$ was heated in a sealed tube at $120^{\circ} \mathrm{C}$ for 30 minutes. Cellulose TLC (Solvent system B) of the solution showed the appearance of leucine ( $R f 0.58)$ and $1(\operatorname{Rf} 0.25)$ in addition to the starting material (Rf 0.53 ). Further hydrolysis of the solution gave $7 \mathrm{a}(\mathrm{Rf} 0.55)$ and $7 \mathbf{b}$ ( $R f$ 0.48) in addition to leucine, 1 and the starting material (trace).

(b) With Carboxypeptidase A: To a suspension of the monohydrochloride of $2 \mathrm{a}(2 \mathrm{mg})$ in water $(0.5 \mathrm{ml}), 1 \%$ aqueous carboxypeptidase A solution $(0.02 \mathrm{ml})$ was added; the mixture was adjusted to pH 8 by addition of $0.05 \mathrm{~N}$ aqueous sodium hydroxide and then digested at $27^{\circ} \mathrm{C}$ for 3 hours. Cellulose TLC (Solvent system B) of the solution showed the appearance of leucine ( Rf 0.58 ) and 1 ( Rf 0.25 ) and the complete disappearance of the starting material ( $\mathrm{Rf} 0.53$ ).

Crude $2 \mathbf{a}$ was also digested with carboxypeptidase $\mathrm{A}$ to give a trace of isoleucine in addition to leucine and 1. By quantitative amino acid analysis the molar ratio of isoleucine and leucine was $1: 14$.

Compound 1 was resistant to the action of carboxypeptidase.

Hydrolysis of $\mathbf{2 b}$. (a) With Hydrochloric Acid: The monohydrochloride of $2 \mathbf{b}(1 \mathrm{mg})$ was hydrolyzed with $0.1 \mathrm{~N}$ hydrochloric acid $(0.1 \mathrm{ml})$ as described for $\mathbf{2 a}$, and showed valine (Rf 0.52) and 1 (Rf 0.25), in addition to the starting material (Rf. 0.51) by cellulose TLC (Solvent system B).

(b) With Carboxypeptidase A: The monohydrochloride of $2 \mathrm{~b}(1 \mathrm{mg})$ digested with $1 \%$ aqueous carboxypeptidase A solution $(0.01 \mathrm{ml})$ as described for $2 \mathrm{a}$ showed only two products, valine ( $\mathrm{Rf} 0.52)$ and 1 ( $R f 0.25$ ), by TLC in the same system.

Complete Hydrolysis of $\mathbf{2 a}$ and $\mathbf{2 b}$. A solution of $\mathbf{2 a}$ and $\mathbf{2 b}(180 \mathrm{mg})$ in $3 \mathbf{N}$ hydrochloric acid (36 ml) was heated in a sealed tube at $140^{\circ} \mathrm{C}$ for 55 hours. Cellulose TLC (Solvent system B) of the solution showed the presence of leucine ( $\mathrm{Rf} 0.58$; purple nihydrin), phenylalanine ( $\mathrm{Rf} 0.57$; blue ninhydrin), valine ( $\operatorname{Rf} 0.52$ ) and $4(\operatorname{Rf} 0.18)$, without $1,7 \mathrm{a}, 7 \mathrm{~b}$ and the starting material. The solution was evaporated to give a residue $(200 \mathrm{mg}$ ), which was chromatographed on a column of silica gel (Wako gel, $70 \mathrm{~g}$ ) with Solvent system D. A mixture of phenylalanine, leucine, and valine, which was eluted in the fraction from $90 \sim 170 \mathrm{ml}$, was chromatographed on a column of Amberlite CG-50 ( $\mathrm{H}$ form) to give DL-phenylalanine $(35 \mathrm{mg})$ and a mixture $(50 \mathrm{mg})$ of L-leucine and L-valine. Substance 4 , which was eluted in the fraction from $230 \sim 530 \mathrm{ml}$, was passed through a short column of Dowex $1 \times 2(\mathrm{OH}$ form) to give the pure free base of $4(46.5 \mathrm{mg})$.

Preparation of 1,2-Di-O-Acetyl-3-Phenylpropane (8). To a solution of $3(130 \mathrm{mg})$ in ethyl ether 
$(5 \mathrm{ml})$ was added ethereal zinc borohydride $(1.3 \mathrm{ml})$, which was prepared according to W. J. GENSLER et al. ${ }^{57}$. After 30 minutes, the solution, which, on silica gel TLC (Solvent system A), showed a single spot of Rf 0.14 instead of the starting material ( $R f 0.50$ ), was evaporated to give a syrup ( $150 \mathrm{mg}$ ). The syrup was passed through a column of silica gel $(15 \mathrm{~g})$ with ethyl acetate and the fraction (26 $60 \mathrm{ml}$ ) containing a substance of $\mathrm{Rf} 0.14$ was evaporated to give 2-hydroxy-3-phenylpropanol as a colorless syrup: yield $120 \mathrm{mg}$. To a solution of the syrup $(55 \mathrm{mg})$ in pyridine $(2 \mathrm{ml})$, acetic anhydride ( $1 \mathrm{ml}$ ) was added and the solution was allowed to stand overnight. After addition of a small volume of ethanol, the solution was evaporated to give a residue, which showed, on silica gel TLC (Solvent system $G)$, a single spot of $\mathrm{Rf} 0.42$. The residue was passed through a column of silica gel $(10 \mathrm{~g})$ with the same solvent system and the fraction $(18 \sim 27 \mathrm{ml})$ containing the substance of Rf 0.42 was evaporated to give 8 as a colorless syrup; yield $78 \mathrm{mg}$ (overall yield from $3: 86 \%) ;[\alpha]_{\mathrm{D}}^{20} 0^{\circ}(\mathrm{c} 1.0$, chloroform).

Found: C 66.18, $\mathrm{H} \mathrm{6.94 \%}$. Calcd. for $\mathrm{C}_{13} \mathrm{H}_{16} \mathrm{O}_{4}$ (mol, wt. 236.26): $\mathrm{C} 66.08, \mathrm{H} 6.83 \%$.

Mass spectrum $(m / e): 236\left(\mathrm{M}^{+}\right), 205,193,176,149,134,133,117,116,115,91,77$.

IR spectrum (neat): $3030,2950(\mathrm{CH}), 1750,1375$ (acetate), $750,700 \mathrm{~cm}^{-1}$ (phenyl).

NMR spectrum $\left(\mathrm{CDCl}_{3}\right): \delta 2.03$ and $2.08($ each $3 \mathrm{H} \mathrm{s}, \mathrm{O}-\mathrm{Ac} \times 2), 2.96\left(2 \mathrm{H} \mathrm{d}, \mathrm{J} 7 \mathrm{~Hz}, \mathrm{CH}_{2}\right), 4.02$ and 4.30 [each $1 \mathrm{H} \mathrm{q} \mathrm{(J} 6$ and $12.5 \mathrm{~Hz}$, and $\mathrm{J} 4$ and $12.5 \mathrm{~Hz}$, respectively), forming the $\mathrm{AB}$ part of an $\mathrm{ABX}$ system], $\sim 5.34(1 \mathrm{H} \mathrm{m}, \mathrm{CH}), 7.35(5 \mathrm{H}$, singlet in appearance, phenyl).

Preparation of Dimethyl Acetal of Chymostatin. To a stirred suspension of chymostatin $(80 \mathrm{mg})$ in methanol $(2 \mathrm{ml})$, conc. hydrochloric acid $(0.1 \mathrm{ml})$ was added and the solution was allowed to stand overnight at room temperature. Cellulose TLC (Solvent system B) of the resulting solution showed that chymostatin $(\mathrm{Rf} \sim 0.7)$ had disappeared and been replaced by the dimethyl acetal (Rf. 0.91). After treatment with methanol-washed Dowex $1 \times 2(\mathrm{OH}$ form), the mixture was filtered and the filtrate was evaporated to give the dimethyl acetal of chymostatin as a colorless solid; yield $80 \mathrm{mg} ; \mathrm{mp} 148 \sim 152^{\circ} \mathrm{C}$ (dec.); $[\alpha]_{D}^{22}+22.5^{\circ}(c 0.5$, dimethylformamide).

Found: $\mathrm{C} 57.08, \mathrm{H} 6.87, \mathrm{~N} 14.27 \%$. These values were substantially in agreement with those calculated for $\mathrm{C}_{33} \mathrm{H}_{47} \mathrm{~N}_{7} \mathrm{O}_{8} \cdot \mathrm{H}_{2} \mathrm{O}$, the component containing only leucine (C 57.62, $\mathrm{H} \mathrm{7.18,} \mathrm{N} \mathrm{14.26 \% ).}$

This compound is slightly soluble in water and methanol.

IR spectrum: $3300 \sim 3100(\mathrm{NH}), 2940(\mathrm{CH}), 1725(\mathrm{COOH}), 1690 \sim 1610$ (guanidinium) ureide and amide I), 1550 (amide II), 750, $700 \mathrm{~cm}^{-1}$ (phenyl).

NMR spectrum (dimethylformamide- $\left.\mathrm{d}_{7}\right): \delta \sim 0.8\left[6 \mathrm{H} \mathrm{m},\left(\mathrm{CH}_{3}\right)_{2}-\mathrm{CH}\right.$ (mainly in Leu and Val)], $1.2 \sim 1.7(3 \mathrm{H} \mathrm{m}), 1.8 \sim 2.1(2 \mathrm{H} \mathrm{m}), 3.0 \sim 3.3(4 \mathrm{H} \mathrm{m}), \sim 3.4(6 \mathrm{H}$, unresolved singlets, dimethyl acetal), $4.0 \sim 4.8(6 \mathrm{H} \mathrm{m}), \sim 7.3(12 \mathrm{H} \mathrm{m}$, two phenyl and two imino protons), $7.5 \sim 8.4(\sim 4 \mathrm{H} \mathrm{m})$.

Preparation of Di- $n$-butyl Acetal of Chymostatin. A sample of chymostatin $(60 \mathrm{mg})$ was treated with $n$-butanol $(2 \mathrm{ml})$ and conc. hydrochloric acid $(0.1 \mathrm{ml})$ as in the preparation of the dimethyl acetal. The resulting solution, which showed a single new spot corresponding to the dibutyl acetal (Rf 0.95) on cellulose TLC (Solvent system B), was treated with Dowex $1 \times 2(\mathrm{OH}$ form) and evaporated to give the dibutyl acetal of chymostatin as a colorless solid; yield $62 \mathrm{mg} ; \mathrm{mp} 135 \sim 141^{\circ} \mathrm{C}$ (dec.); $[\alpha]_{D}^{22}+10^{\circ}$ (c 1.0, dimethylformamide).

Found: $\mathrm{C} 59.98, \mathrm{H} 7.41, \mathrm{~N} 13.01 \%$. These values were essentially in agreement with those calculated for $\mathrm{C}_{39} \mathrm{H}_{59} \mathrm{~N}_{7} \mathrm{O}_{8} \cdot \mathrm{H}_{2} \mathrm{O}$, the component containing only leucine (C 60.68, H 7.97, N 12.70\%).

This compound is soluble in water and methanol.

IR spectrum: $3300 \sim 3100(\mathrm{NH}), 2940(\mathrm{CH}), 1725(\mathrm{COOH}), 1690 \sim 1610$ (guanidinium, ureide and amide I), 1550 (amide II), 750, $700 \mathrm{~cm}^{-1}$ (phenyl).

NMR spectrum (dimethylformamide- $\left.\mathrm{d}_{7}\right): \delta 0.5 \sim 1.15(14 \mathrm{H} \mathrm{m}), 1.15 \sim 1.7(9 \mathrm{H} \mathrm{m}), 1.7 \sim 2.2(2 \mathrm{H} \mathrm{m})$, $2.9 \sim 3.3(4 \mathrm{H} \mathrm{m}), 3.3 \sim 3.7\left(4 \mathrm{H} \mathrm{m}\right.$, two $\mathrm{O}-\mathrm{CH}_{2}$ of dibutyl acetal), $4.0 \sim 5.2(6 \mathrm{H} \mathrm{m}), 7.3(11 \mathrm{H} \mathrm{m}$, two phenyl and one imino protons), $7.5 \sim 8.5(\sim 5 \mathrm{H} \mathrm{m})$. The presence of 23 proton-signals at $\delta 0.5 \sim 1.7$ was in accord with two chains $-\mathrm{CH}_{2} \mathrm{CH}_{2} \mathrm{CH}_{3}$ of dibutyl acetal in addition to the $\left(\mathrm{CH}_{3}\right)_{2} \mathrm{CH}$ - of leucine or valine moieties in the molecule.

Oxidation of Chymostatin (Formation of 9). To a suspension of chymostatin $(720 \mathrm{mg})$ in water ( $30 \mathrm{ml}$ ), potassium permanganate $(500 \mathrm{mg})$ was added and the mixture was vigorously stirred at room temperature. After 30 minutes, cellulose TLC (Solvent system B) of the reaction mixture showed that the starting material ( $\mathrm{Rf} \sim 0.7)$ had disappeared and a new spot $(9 ; \mathrm{Rf} 0.57$ ) had appeared. The 
mixture was filtered with the aid of Celite and the filtrate was evaporated with several additions of butanol to give a residue, which was mixed with cellulose powder $(3 \mathrm{~g})$. The mixture was applied to a column of cellulose powder $(200 \mathrm{~g})$ and then developed with Solvent system B. The fraction (300 $420 \mathrm{ml}$ ) containing a substance at $\mathrm{Rf} 0.57$ was evaporated to give 9 as a colorless solid; yield $413 \mathrm{mg}$; mp $175 \sim 181^{\circ} \mathrm{C}$ (dec.), $[\alpha]_{\mathrm{D}}^{22}+5.5^{\circ}$ (c 1.0, acetic acid). The elemental analysis of 9 showed $\mathrm{C} 57.39$, $\mathrm{H} 6.75$ and $\mathrm{N} 14.98 \%$, which was substantially in agreement with the values (C 58.01, H 6.75, N $15.28 \%$, calculated for $\mathrm{C}_{31} \mathrm{H}_{41} \mathrm{~N}_{7} \mathrm{O}_{7} \cdot \mathrm{H}_{2} \mathrm{O}$, the component containing leucine.

Compound 9 is positive to RYDON-SMITH but negative to TTC.

IR spectrum: $\sim 3300(\mathrm{NH}), 2960(\mathrm{CH}), 1740,1710$ (sh., COOH), 1700 1650, $\sim 1630$ (guanidinium, ureide and amide I), $\sim 1560$ (amide II), 800, 755, 725 and $700 \mathrm{~cm}^{-1}$ (phenyl).

NMR spectrum $\left(\mathrm{CF}_{3} \mathrm{COOD}\right): \delta 0.7 \sim 1.2\left[6 \mathrm{H} \mathrm{m},\left(\mathrm{CH}_{3}\right)_{2} \mathrm{CH}\right.$ (in Leu and Val)], $1.3 \sim 1.7(2 \mathrm{H} \mathrm{m})$, $1.7 \sim 2.3(3 \mathrm{H} \mathrm{m}), 3.0 \sim 3.7(6 \mathrm{H} \mathrm{m}), 4.3 \sim 5.3(4 \mathrm{H} \mathrm{m}), \sim 7.3(10 \mathrm{H} \mathrm{m}$, two phenyl protons). The aldehyde proton was not observed.

The C-terminal amino acid analysis of 9 gave only phenylalanine.

Acid Hydrolysis of 9 (Isolation of 10a and 10b). A sample of $9(350 \mathrm{mg})$ in $1 \mathrm{~N}$ hydrochloric acid $\left(25 \mathrm{ml}\right.$ ) was heated in a sealed tube at $120^{\circ} \mathrm{C}$ for 40 minutes. Cellulose TLC (Solvent system B) showed the appearance of RYDON-SMITH-positive spots of $\operatorname{Rf} 0.53(2 \mathrm{a}), 0.51(2 \mathrm{~b})$ and $0.25(1)$ and the appearance of nihydrin-positive spots of Rf $0.64(\mathbf{1 0 a}), 0.63(\mathbf{1 0 b}), 0.58$ (leucine), 0.57 (phenylalanine) and 0.52 (valine), in addition to the starting material ( $R f 0.57$; RYDON-SMITH positive). The starting material and phenylalanine had identical mobilities, but they were distinguished by the difference in coloration. The solution was evaporated to a residue, which was chromatographed on a column of cellulose powder $(250 \mathrm{~g})$ with the same solvent system. A mixture $(75 \mathrm{mg})$ of $10 \mathrm{a}$ (Rf. 0.64$)$ and $10 \mathrm{~b}(\mathrm{Rf} 0.63)$, a mixture $(130 \mathrm{mg}$ ) of leucine (Rf 0.58), phenylalanine (Rf 0.57) and 9 (Rf 0.57 ), a mixture (60 $\mathrm{mg}$ ) of $2 \mathrm{a}$ (Rf 0.53 ), $\mathbf{2 b}(\operatorname{Rf} 0.51)$ and valine $(\operatorname{Rf} 0.52)$, and $1(\operatorname{Rf} 0.25 ; 60 \mathrm{mg})$, were eluted in this order in fractions from $420 \sim 570,570 \sim 795,795 \sim 900$ and $990 \sim 1,125 \mathrm{ml}$, respectively. The mixture $(75 \mathrm{mg})$ of $10 \mathrm{a}$ and $10 \mathrm{~b}$ was chromatographed on a column of CM-Sephadex $\mathrm{C}-25\left(\mathrm{NH}_{4}^{+}\right.$form, $\left.24 \times 200 \mathrm{~mm}\right)$ with water. The fraction collected from $72 \sim 104 \mathrm{ml}$ was evaporated to give a colorless solid. Recrystallization from aqueous ethanol gave the monohydrate of $10 \mathrm{a}$; yield $35 \mathrm{mg}$; $\mathrm{mp} 124 \sim 125^{\circ} \mathrm{C},[\alpha]_{\mathrm{D}}^{33}+27.5^{\circ}(c 1.0$, methanol).

Found: C 60.59, H 7.81, N 9.18\%. Calcd. for $\mathrm{C}_{15} \mathrm{H}_{22} \mathrm{~N}_{2} \mathrm{O}_{3} \cdot \mathrm{H}_{2} \mathrm{O}: \mathrm{C} 60.79, \mathrm{H} 8.16, \mathrm{~N} 9.45 \%$. IR spectrum: $\sim 3450(\mathrm{OH}), 3300(\mathrm{NH}), 2940(\mathrm{CH}), \sim 2600(\mathrm{NH}), 1680$ (amide $\mathrm{I}), \sim 1615\left(\mathrm{COO}^{-}\right)$, $1560\left(\mathrm{NH}_{3}^{+}\right), 1530$ (amide II), $1390\left(\mathrm{COO}^{-}\right), 745,720,695 \mathrm{~cm}^{-1}$ (phenyl).

NMR spectrum $\left(\mathrm{CF}_{3} \mathrm{COOD}\right): \delta 0.85 \sim 1.15\left[6 \mathrm{H} \mathrm{m}, \mathrm{CH}\left(\mathrm{CH}_{3}\right)_{2}\right.$ (in Leu)], $1.4 \sim 1.7[1 \mathrm{H} \mathrm{m}, \mathrm{CH}$ (in Leu)], $\sim 1.85$ [2H m, $\mathrm{CH}_{2}$ (in Leu)], 2.9 3.7 [2H m, $\mathrm{CH}_{2}$ (in Phe)], $\sim 4.35$ [1 $\mathrm{H} \mathrm{m}, \mathrm{CH}$ (in Leu)], $\sim 5.1$ [1H m, CH (in Phe)], 7.1 7.5 [5H m, phenyl (in Phe)].

A solution of $10 \mathrm{a}(71 \mathrm{mg})$ in $6 \mathrm{~N}$ hydrochloric acid $(5 \mathrm{ml})$ was heated in a sealed tube at $120^{\circ} \mathrm{C}$ for 6 hours and then the solution was evaporated to a residue, which was chromatographed on a column of CM-Sephadex C-25 ( $\mathrm{H}$ form, $17 \times 180 \mathrm{~mm}$ ) with water. The fraction $(50 \sim 106 \mathrm{ml})$ containing leucine was evaporated and recrystallized from aqueous ethanol to give L-leucine as colorless plates; yield $24 \mathrm{mg} ;[\mathrm{M}]_{\mathrm{D}}^{21}-14^{\circ}$ (c 1.0, water). The fraction from 106 162 $\mathrm{ml}$ was evaporated and recrystallized from water to give DL-phenylalanine as colorless plates; yield $22 \mathrm{mg} ;[\mathrm{M}]_{\mathrm{D}}^{21} 0^{\circ}(c 0.75$, water).

In physicochemical properties, $10 \mathrm{a}$ was identical with L-leucyl-DL-phenylalanine which was synthesized in the usual way.

From the first CM-Sephadex column chromatography, the fraction from 104 120 $\mathrm{ml}$ was evaporated to give $10 \mathrm{~b}$ as a colorless solid, which was recrystallized from aqueous ethanol; yield $21 \mathrm{mg} ; \mathrm{mp}$ $130 \sim 131^{\circ} \mathrm{C},[\alpha]_{D}^{23}+36.3^{\circ}$ (c 0.93, methanol).

Found: C 59.31, H 7.43, N 9.70\%. Calcd. for $\mathrm{C}_{14} \mathrm{H}_{20} \mathrm{~N}_{2} \mathrm{O}_{3} \cdot \mathrm{H}_{2} \mathrm{O}$ : C 59.55, H 7.85, N 9.92\%.

IR spectrum: $\sim 3400(\mathrm{OH}), \sim 3250(\mathrm{NH}), 3040,2960(\mathrm{CH}), 1680$ (amide I), $1625\left(\mathrm{COO}^{-}\right), \sim 1575$ $\left(\mathrm{NH}_{3}^{+}\right), 1530$ (amide II), $1395\left(\mathrm{COO}^{-}\right), 740,720,695 \mathrm{~cm}^{-1}$ (phenyl).

NMR spectrum $\left(\mathrm{CF}_{3} \mathrm{COOD}\right): \delta 0.81$ and 0.95 [each $1.5 \mathrm{H}\left(3 \mathrm{H}\right.$ in total) $\mathrm{d}, \mathrm{J} 7 \mathrm{~Hz}, \mathrm{CH}\left(\mathrm{CH}_{3}\right)_{2}$ (in Val)], 1.41 and 1.16 [each $1.5 \mathrm{H}$ (3H in total) d, $\mathrm{J} \sim 7 \mathrm{~Hz}, \mathrm{CH}\left(\mathrm{CH}_{3}\right)_{2}$ (in Val)], $2.0 \sim 2.6[1 \mathrm{H} \mathrm{m}, \mathrm{CH}$ (in




7.5 [5H m, phenyl (in Phe)].

Compound 10b was hydrolyzed with $6 \mathrm{~N}$ hydrochloric acid as described above to give L-valine and DL-phenylalanine. It was identical in $\mathrm{mp}, \mathrm{IR}, \mathrm{NMR}$ and optical rotation with L-valyl-DL-phenylalanine which was synthesized in the usual manner.

EDMAN degradations of $10 \mathrm{a}$ and $10 \mathrm{~b}$ gave phenylthiohydrantoins of leucine and valine, respectively, from thier $\mathrm{N}$-terminal residues, and both phenylalanine as the $\mathrm{C}$-terminal residue.

The other constituents $\mathbf{1}(48 \mathrm{mg}), \mathbf{2 a}(25 \mathrm{mg}), \mathbf{2 b}(8 \mathrm{mg}), 9(18 \mathrm{mg})$, L-leucine $(28 \mathrm{mg})$, DL-phenylalanine $(41 \mathrm{mg})$ and L-valine $(5 \mathrm{mg})$ were isolated by the appropriate purification method described in preceding sections.

Enzymatic Hydrolysis of 9. Compound $9(3 \mathrm{mg})$ was digested with carboxypeptidase A. The method used here was virtually identical with that described for the enzymatic hydrolysis of 2a. After 30 minutes, cellulose TLC (Solvent system B) showed the appearance of $2 \mathbf{a}$ (Rf 0.53 ; major), $2 \mathbf{b}(0.51$; minor) and phenylalanine (presumably L-isomer; 0.57 ; major) in addition to the unchanged starting material $9_{\mathrm{D}}$ (presumably containing D-phenylalanine as a C-terminal amino acid; Rf 0.57 ). After 3 hours, cellulose TLC showed the presence of ninhydrin-positive spots corresponding to L-leucine (Rf 0.58 ; major), L-phenylalanine ( 0.57 ; major) and L-valine $(0.52$; minor), and the presence of a RYDONSMrTH-positive spot corresponding to 1 (Rf 0.25 ; major), in addition to the unreacted starting material 9D (0.57). On TLC, paper chromatography, and high voltage paper electrophoresis, leucine and isoleucine had identical mobility and were indistinguishable from each other, but by quantitative amino acid analysis they were distinguishable and the molar ratios of phenylalanine, leucine, valine and isoleucine were $16: 10: 2: 1$.

Isolation of D-Phenylalanine from D-Phenylalanine-containing $9_{\mathrm{D}}$. A sample of $9(100 \mathrm{mg})$ was hydrolyzed with carboxypeptidase $\mathrm{A}$ at $27^{\circ} \mathrm{C}$ for 12 hours, as described above. The hydrolysate was chromatographed on a column of cellulose powder $(30 \mathrm{~g})$ with Solvent system B. A mixture of $9_{\mathrm{D}}$, L-leucine, L-valine and L-phenylalanine, was eluted in the fractions from $63 \sim 93 \mathrm{ml}$, and compound 1 apparent at $117 \sim 159 \mathrm{ml}$. The former fraction was evaporated to a residue, which was then chromatographed with a column of Amberlite CG-50 (H form, $12 \times 130 \mathrm{~mm})$; water $(60 \mathrm{ml})$ eluted leucine, phenylalanine and valine. Subsequent development with $1 \mathrm{~N}$ ammonia eluted $9 \mathrm{p}$ in the fraction from $32 \sim 64 \mathrm{ml}$; it was obtained as a colorless solid, $24 \mathrm{mg}$.

A solution of $9_{D}(24 \mathrm{mg})$ in a mixture of acetic acid $(2 \mathrm{ml})$ and $3 \mathrm{~N}$ hydrochloric acid $(3 \mathrm{ml})$ was heated in a sealed tube at $120^{\circ} \mathrm{C}$ for 3 hours and the solution was evaporated. Cellulose TLC (Solvent system B) of the residue showed the presence of leucine ( $\operatorname{Rf} 0.58$ ), phenylalanine $(0.57)$, valine $(0.52)$ and $1(0.25)$. The residue was chromatographed on a column of cellulose powder $(5 \mathrm{~g})$ with the same solvent system. A mixture $(70 \mathrm{mg})$ of leucine and phenylalanine, which was eluted in the fraction from $14 \sim 23 \mathrm{ml}$, was again chromatographed on a column of CM-Sephadex C-25 (H form, $12 \times 115 \mathrm{~mm}$ ) with water. The fraction $(46 \sim 52 \mathrm{ml})$ containing phenylalanine was evaporated and recrystallized from water to give $\mathrm{D}$-phenylalanine as colorless plates; $2 \mathrm{mg} ;[\mathrm{M}]_{\mathrm{D}}^{17}+54^{\circ}\left(\mathrm{c} 0.25\right.$, water) $\left[\right.$ lit, ${ }^{3 \mathrm{c})}:[\mathrm{M}]_{\mathrm{D}}^{25}+57.0^{\circ}$ (water)]. The IR spectrum of this sample was superimposable on that of authentic D-phenylalanine.

Upon enzymatic hydrolysis, $9_{D}$ remained unchanged owing to the presence of D-phenylalanine as one of the C-terminal residues (the other one is the $\mathrm{L}$-isomer on moiety $\mathbf{1}$ ).

\section{Acknowledgements}

The authors are grateful to Dr. Tsutomu Tsuchiya for his interest in this work and wish to thank Dr. Hiroshi Naganawa for NMR studies, Dr. Tomohisa Takita of the Institute of Microbial Chemistry for supplying the sample of capreomycidine and Mr. SABURO NAKADA for the elemental analyses.

\section{References}

1) Umezawa, H.; T. Aoyagt, H. Morishima, S. Kunimoto, M. Matsuzaki, M. Hamada \& T. Takeuchi: Chymostatin, a new chymotrypsin inhibitor produced by actinomycetes. J. Antibiotics 23: 425 427, 1970

2) a) Herr, E. B., Jr.: Chemical and biological properties of capreomycin and other peptide antibiotics. 
Antimicr. Agents \& Chemoth. -1962: $201 \sim 212,1963$

b) Bycroft, B. W.; D. Cameron, L. R. Croft \& A. W. Johnson: Synthesis and stereochemistry of capreomycidine [ $\alpha$-(2-iminohexahydro-4-pyrimidyl)glycine]. Chem. Comm. 1968: 1301 1302, 1968

c) TAKITA, T.\& K. MAEDA: The structure of the guanido amino acid moiety of viomycin. J. Antibiotics $21: 512 \sim 516,1968$

3) a) Greenstein, J. P. \& M. Winitz: "Chemistry of the Amino Acids", Vol. 1, p. 83, John Wiley, New York, 1961

b) Vol. 3, p. 2075

c) Vol. 3, p. 2156

d) Vol. 3, p. 2368

4) WARE, E.: The chemistry of the hydantoins. Chem. Revs. 46: $403 \sim 470,1950$

Mouneyrat, A.: Verwandlung der $\alpha$-Aminosäuren in Phenylhydrantoine. Chem. Ber. 33: 2393 2396, 1900

DAKIN, H. D.: Catalytic racemization of optically active hydantoin derivatives and of related substances as the result of tautomeric change. Am. Chem. J. 44: 48 60, 1910

5) Gensler, W. J.; F. Johnson \& A. D. B. Sloan: Compounds related to podophyllotoxin. XII. Podophyllotoxone, picropodophyllone and dehydropodophyllotoxin. J. Amer. Chem. Soc. 82: 6074 6081, 1960

6) Edman, P.: Determination of the amino acid sequence in peptides. Arch. Biochem. 22: 475 476, 1949

7) a) Suda, H.; T. Aoyagi, M. Hamada, T. Takeuchi \& H. Umezawa: Antipain, a new protease inhibitor isolated from Actinomycetes. J. Antibiotics 25: 263 266, 1972

b) Umezawa, S.; K. Tatsuta, K. Fujmoto, T. Tsuchiya, H. Umezawa \& H. Naganawa: Structure of antipain, a new SAKaGUCHI-positive product of streptomyces. J. Antibiotics 25: 267 270, 1972

8) Fisher, H. E. \& H. Hibbert: Studies on lignin and related compounds. LXXXIII. Synthesis of 3hydroxy-1-(4-hydroxy-3-methoxyphenyl)-2-propanone. J. Amer. Chem. Soc. 69: 1208 1210, 1947

9) Rydon, H. N. \& P. W. G. Smith: A new method for the detection of peptides and similar compounds on paper chromatograms. Nature 169: $922 \sim 923,1952$ 